\title{
CONTRIBUTING RECHARGE AREAS TO WATER-SUPPLY WELLS AT WRIGHT- PATTERSON AIR FORCE BASE, OHIO
}

by Rodney A. Sheets

U.S. GEOLOGICAL SURVEY

Water-Resources Investigations Report 94-4231

Prepared in cooperation with

WRIGHT-PATTERSON AIR FORCE BASE

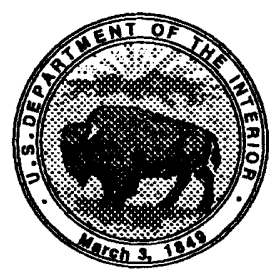

Columbus, Ohio 1994 


\title{
U.S. DEPAR'TMENT OF THE INTERIOR \\ BRUCE BABBIT, Secretary
}

\author{
U.S. GEOLOGICAL SURVEY \\ GORDON P. EATON, Director
}

For additional information write to:

District Chief

Water Resources Division

U.S. Geological Survey

975 West Third Avenue

Columbus, OH 43212-3192
Copies of this report may

be purchased from:

U.S. Geological Survey

Earth Science Information Center

Open-File Reports Section

Box 25286, MS 517

Denver Federal Center

Denver, CO 80225 


\section{CONTENTS}

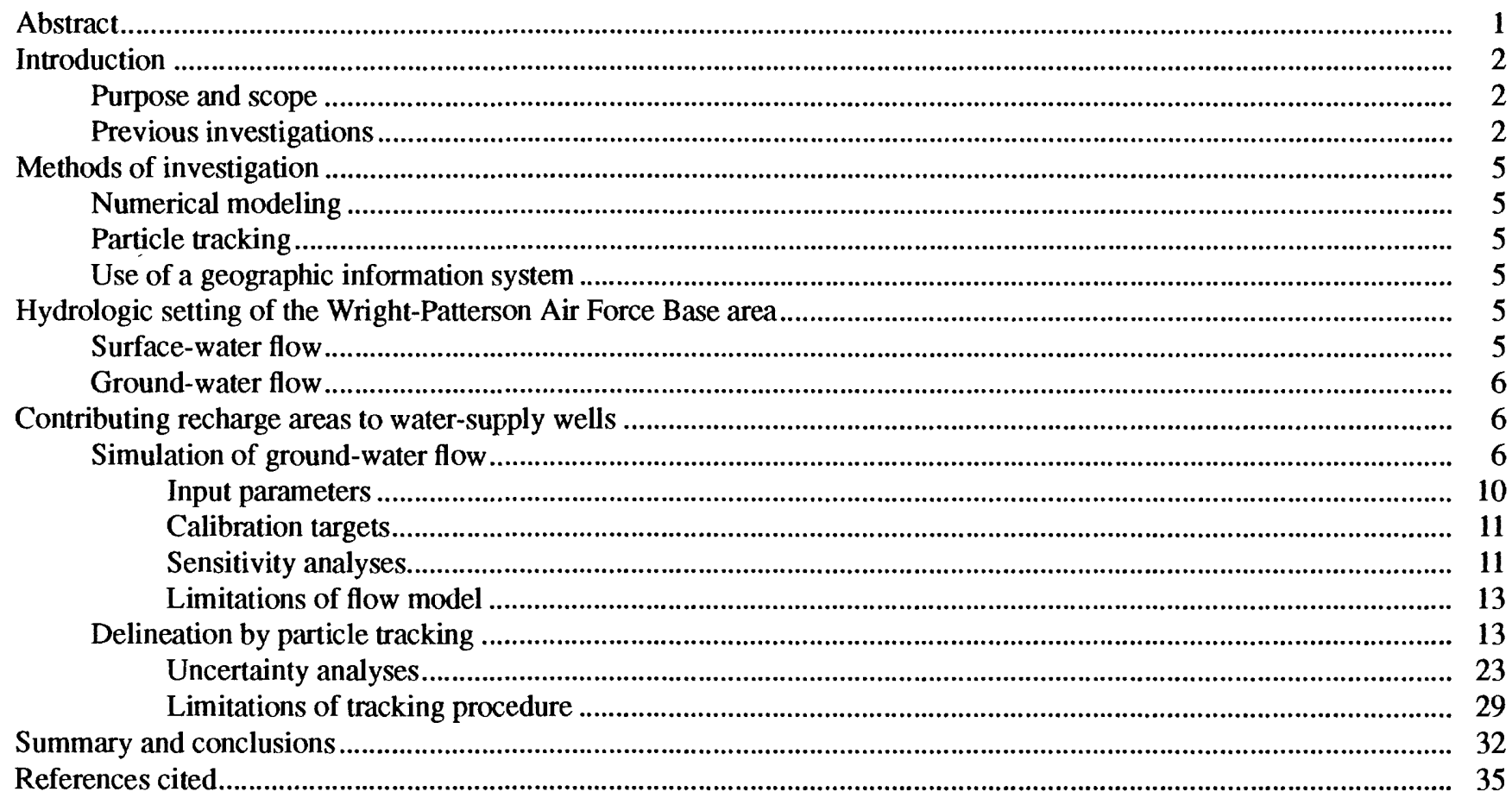

\section{FIGURES}

1-3. Maps showing:

1. Location of Wright-Patterson Air Force Base and administrative areas............................................................ 3

2. Location of well fields in the study area ................................................................................................. 4

3. Ground-water levels and generalized flow directions in the upland bedrock and valley-train deposits

4. Contributing recharge area to a single discharging well in a simplified hypothetical

ground-water-flow system .....

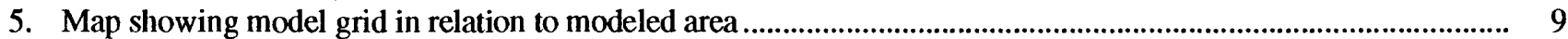

6. Generalized sectional view of the ground-water-flow model, Wright-Patterson Air Force Base, Ohio .................... 10

7-10. Graphs showing:

7. Sensitivity of simulated heads to changes in horizontal hydraulic conductivity, riverbed conductance, and vertical hydraulic conductance in model of ground-water-flow system,

Wright-Patterson Air Force Base, Ohio, and vicinity

8. Sensitivity of simulated flows to Mad River South and Hebble Creek to changes in hydrogeologic parameters in the model of the ground-water-flow system, Wright-Patterson Air Force Base, Ohio

9. Sensitivity of simulated flows from Hills 1 and 2 to changes in hydrogeologic parameters in the model of the ground-water-flow system, Wright-Patterson Air Force Base, Ohio.

10. Sensitivity of simulated flows under Huffman Dam to changes in hydrogeologic parameters in the model of the ground-water-flow system, Wright-Patterson Air Force Base, Ohio

11. Map showing 1-, 5-, and 10-year contributing recharge areas to the Skeel Road and East Well Fields 
12-14. Maps showing contributing recharge areas to Skeel Road and Area B Well Fields:

12. Under normal pumping conditions

13. Under intermediate pumping conditions....

14. Under maximum capacity pumping conditions

15. Graphs showing change in contributing recharge areas in relation to pumping rates at

Skeel Road and Area B Well Fields, Wright-Patterson Air Force Base, Ohio

16-18. Maps showing contributing recharge areas to the East Well Field:

16. Under October-December 1987 pumping conditions

17. Under intermediate pumping conditions

18. Under maximum capacity pumping conditions

19-20. Graphs showing variations of the contributing recharge areas of Skeel Road Well Field,

Wright-Patterson Air Force Base, Ohio, in relation to changes:

19. In horizontal hydraulic conductivity of the upland bedrock and the buried-valley aquifer, under normal pumping conditions

20. Of porosity of the upland bedrock and the buried-valley aquifer, under normal pumping conditions.

21-23. Graphs showing variations of the contributing recharge areas of Area B Well Field,

Wright-Patterson Air Force Base, Ohio, in relation to changes:

21. Of horizontal hydraulic conductivity of the upland bedrock and buried-valley aquifer, under normal pumping conditions....

22. Of porosity of the upland bedrock and buried-valley aquifer, under normal pumping conditions

23. Of riverbed conductance, under normal pumping conditions

24. Contributing recharge areas to the Skeel Road and Area B Well Fields,

under current (1994) pumping conditions, including pumping of wells at Huffman Dam.

\section{TABLES}

1. Pumping rates and contributing recharge areas to well fields at Wright-Patterson Air Force Base, Ohio

\section{CONVERSION FACTORS}

\begin{tabular}{|c|c|c|}
\hline Multiply & By & To obtain \\
\hline \multicolumn{3}{|c|}{ Length } \\
\hline inch (in.) & 25.4 & millimeter \\
\hline foot $(f t)$ & 0.3048 & meter \\
\hline mile (mi) & 1.609 & kilometer \\
\hline \multicolumn{3}{|c|}{ Area } \\
\hline square foot $\left(\mathrm{ft}^{2}\right)$ & 0.09290 & square meter \\
\hline square mile $\left(\mathrm{mi}^{2}\right)$ & 2.590 & square kilometer \\
\hline \multicolumn{3}{|c|}{ Volume } \\
\hline gallon (gal) & 3.785 & liter \\
\hline \multicolumn{3}{|c|}{ Flow } \\
\hline million gallons per day (Mgal/d) & 0.04381 & cubic meters per second \\
\hline foot per day $(\mathrm{ft} / \mathrm{d})$ & 0.3048 & meter per day \\
\hline foot squared per day $\left(\mathrm{ft}^{2} / \mathrm{d}\right)$ & 0.09290 & meter square per day \\
\hline
\end{tabular}

Temperature is given in degrees Celsius $\left({ }^{\circ} \mathrm{C}\right)$, which can be converted to degrees Fahrenheit $\left({ }^{\circ} \mathrm{F}\right)$ by use of the following equation:

$$
\mathrm{F}=1.8\left({ }^{\circ} \mathrm{C}\right)+32
$$

Sea level: In this report, "sea level" refers to the National Geodetic Vertical Datum of 1929 (NGVD of 1929) - a geodetic datum derived from a general adjustment of the first-order level nets of both the United States and Canada, formerly called Sea Level Datum of 1929. 


\title{
Contributing Recharge Areas of Water-Supply Wells at Wright-Patterson Air Force Base, Ohio
}

\author{
By Rodney A. Sheets
}

\section{Abstract}

Wright-Patterson Air Force Base, in southwestern Ohio, has operated three well fieldsArea B, Skeel Road, and the East Well Fields-to supply potable water for consumption and use for base activities. To protect these well fields from contamination and to comply with the Ohio Wellhead Protection Plan, the Base is developing a wellhead-protection program for the well fields.

A three-dimensional, steady-state groundwater-flow model was developed in 1993 to simulate heads in (1) the buried-valley aquifer system that is tapped by the two active well fields, and in (2) an upland bedrock aquifer that may supply water to the wells. An advective particle-tracking algorithm that requires estimated porosities and simulated heads was used to estimate groundwater-flow pathlines and traveltimes to the active well fields. Contributing recharge areas (CRA's) areas on the water table that contribute water to a well or well field-were generated for 1-, 5-, and 10-year traveltimes.

Results from the simulation and subsequent particle tracking indicate that the CRA's for the Skeel Road Well Field are oval and extend northward, toward the Mad River, as pumping at the well field increases. The sizes of the 1-, 5-, and 10year CRA's of Skeel Road Well Field, under maximum pumping conditions, are approximately 0.5 , 1.5 , and 3.2 square miles, respectively. The CRA's for the Area B Well Field extend to the north, up the Mad River Valley; as pumping increases at the well field, the CRA's extend up the Mad River Valley under Huffman Dam. The sizes of the 1-, 5-, and 10-year CRA's of Area B Well Field, under maximum pumping conditions, are approximately
$0.1,0.5$, and 0.9 square miles, respectively.. The CRA's for the East Well Field are affected by nearby streams under average pumping conditions. The sizes of the 1-, 5-, and 10-year CRA's of the East Well Field, under maximum pumping conditions, are approximately $0.2,1.2$, and 2.4 square miles, respectively. However, as pumping increases at the East Well Field, the groundwater-flow model develops numerical instabilities which limit the usefulness of the CRA's.

Sensitivity analyses show that variation of horizontal hydraulic conductivity and porosity in the upland bedrock does not affect the CRA's of the Skeel Road Well Field but does have a slight affect on the CRA's of the Area B Well Field. Uncertainties in horizontal hydraulic conductivity and porosity of the valley-train deposits have the largest effect on the size and shape of the CRA's of the Skeel Road Well Field. The position and size of the CRA's of Area B are probably also controlled by induced infiltration from the nearby Mad River and by pumping at the Rohrer's Island Well Field. However, uncertainty in riverbed conductance, which affects induced infiltration, does not significantly affect the size and shape of these CRA's.

Pumping centers not included in the groundwater-flow model do not appreciably affect the CRA's of the Area B and Skeel Road Well Fields under normal pumping. The pumping centers, located near Huffman Dam, will probably limit the northern extent of the CRA's of Area B Well Field under greater than normal pumping conditions. The CRA's of the East Well Field will propagate farther to the northeast and southwest as a result of the increased pumping-related stress to the aquifer system. 


\section{INTRODUCTION}

Officially recognized as a Department of Defense facility in 1948, Wright-Patterson Air Force Base (hereafter referred to as "WPAFB" or "the Base") is one of the most important U.S. Air Force installations in the world. Environmental effects of day-to-day operations and waste disposal were rarely considered in the past and these activities at the Base have had an adverse effect on the water quality on the Base (Weston, Incorporated, 1983).

Located in Greene, Clark, and Montgomery Counties in southwestern Ohio, the Base encompasses approximately 8,500 acres and is divided into two administrative areas-Areas A and C, and Area B (fig. 1). The Base overlies the Mad River buried-valley aquifer, which consists of highly permeable glacialdrift deposits. This aquifer is heavily used for water supplies, including supplies for the cities of Dayton and Fairborn, for the Base, and for industrial users. Several studies began in the 1980's to identify and control subsurface migration of environmental contamination on and off the Base. One of these studies by the U.S. Geological Survey (USGS) examined the ground-water-flow system of the area by use of a numerical ground-water-flow model and other techniques (Dumouchelle and others, 1993). The model was developed to help Base officials and researchers better understand regional ground-water flow.

The Base currently (1994) operates two watersupply well fields on Base property-Skeel Road Well Field and Area B Well Field (fig. 2). Skeel Road Well Field also includes a well used for the Base Commissary. Pumping at the East Well Field (fig. 2) was suspended in 1987 because of water-quality concerns (L. Rodgers, Wright-Patterson Air Force Base, oral commun., 1993). All wells in the three well fields are completed in the buried-valley aquifer.

The Ohio Environmental Protection Agency (OEPA), through its Wellhead Protection (WHP) Program, has recommended that all water-supply facilities that rely on ground water develop a WHP strategy that includes establishing protection areas around wells (Ohio Environmental Protection Agency, 1992). No specific enabling legislation exists for the WHP Program, but under the Federal Safe Drinking Water Act Amendments of 1986, the State is required to fully implement the Program. Several WHP area delineation methods based on ground-water traveltime are acceptable under the WHP Program, including calculated-fixed-radius, analytical, semi-analytical, and numerical. An inventory of hazardous-material storage and handling areas including landfills and buildings, can be used in combination with the delineation methods described here to develop a.WHP program. Owing in part to OEPA recommendations, the Base has begun a WHP program to help protect all three well fields from contamination. The USGS, in cooperation with the WPAFB, has simulated groundwater flow and used particle-tracking to delineate contributing recharge areas to water-supply wells on the Base.

\section{Purpose and Scope}

The purpose of this report is to describe the delineation of contributing recharge areas (CRA's) of water-supply well fields at Wright-Patterson Air Force Base. The CRA's are based on simulated ground-water flow from a previously calibrated numerical groundwater-flow model of the area. A particle-tracking scheme that uses hydraulic heads and flow-distribution output from the model is used to calculate groundwater-flow traveltimes. The areal extent of the CRA's is described relative to pumping conditions and variations in model parameters. Limitations of the flow model, particle tracking, and the CRA's also are discussed.

\section{Previous Investigations}

Studies of the water resources of the WPAFB area began in the 1940's. Several site-specific studies have focussed on the geology and hydrology of the known waste disposal or storage sites on the Base (Roy F. Weston, Incorporated, 1983, 1989; Dames \& Moore, 1986a, 1986b; IT Corporation, 1990). Dumouchelle and others (1993) describe the studies important to the development of a regional groundwater-flow model and also outline the results of previous studies by the USGS, including regional groundwater-level and bedrock-configuration maps. Dumouchelle and others (1993) also summarize several studies pertaining to the hydrology of the areas surrounding WPAFB. 


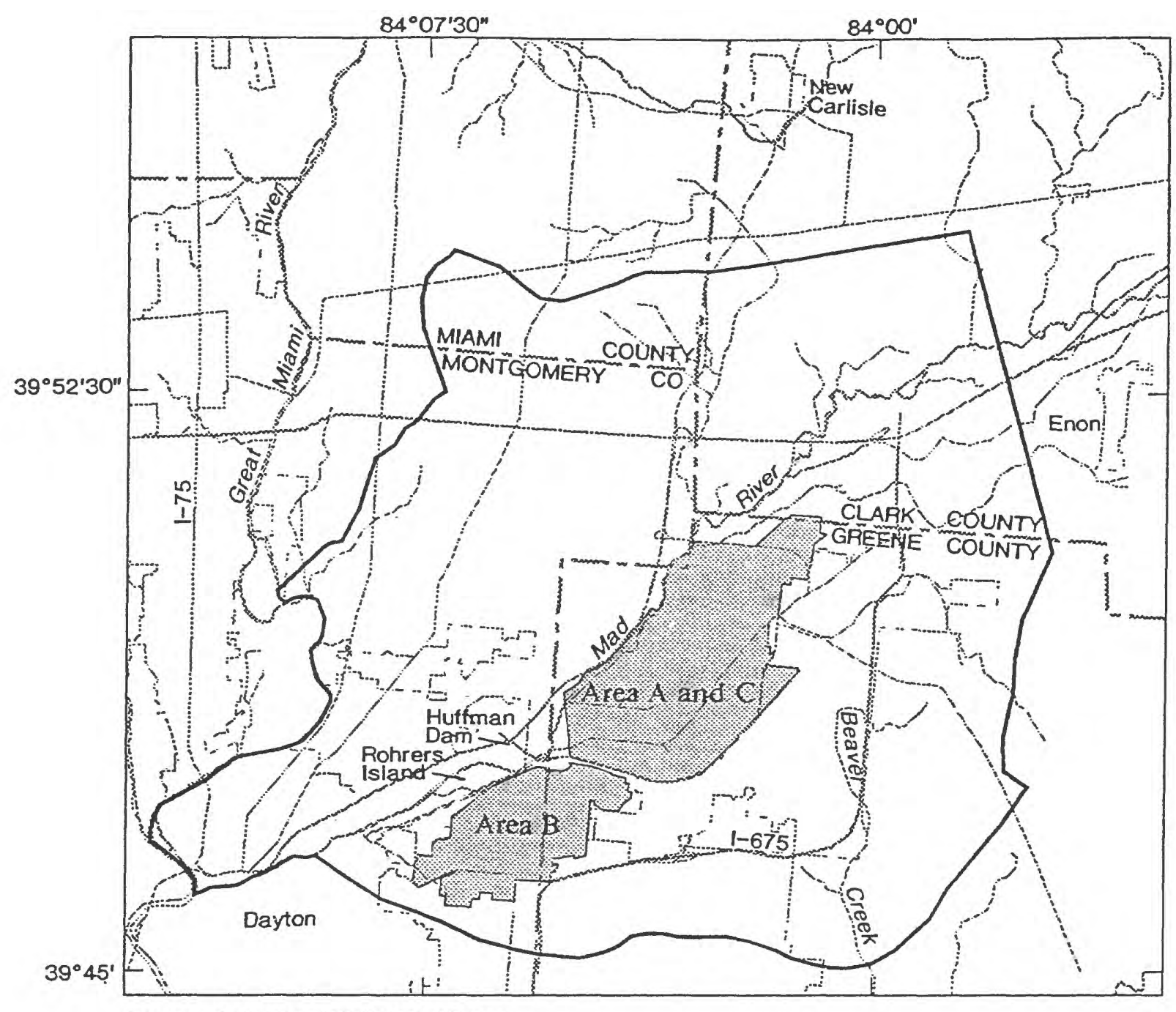

Base map digitized from U.S. Geological Survey Bellbrook, 1965, photorevised 1987: Dayton North 1965. photorevised 1981: Dayton South. 1966. photorevised 1981: Donnelsville, 1965,

photorevised 1973. photoinspected 1983:

Fairbom. 1965. photorevised 1988; New Cartisle.

1955 photorevised 1968 and 1973

photoinspected 1984: Tipp City. 1965,

photorevised 1982, Xenia, 1965, photorevised

1987: Yellow Springs, 1968, pholorevised 1975.

Polyconic projection

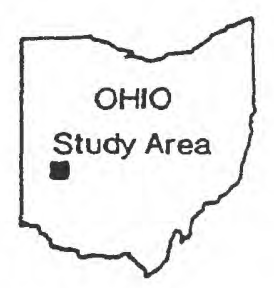

\section{EXPLANATION}

WRIGHT-PATTERSON AIR FORCE BASE

- MODELED-AREA BOUNDARY

Figure 1. Location of Wright-Patterson Air Force Base and administrative areas. (From Dumouchelle and others, 1993, fig. 1.) 


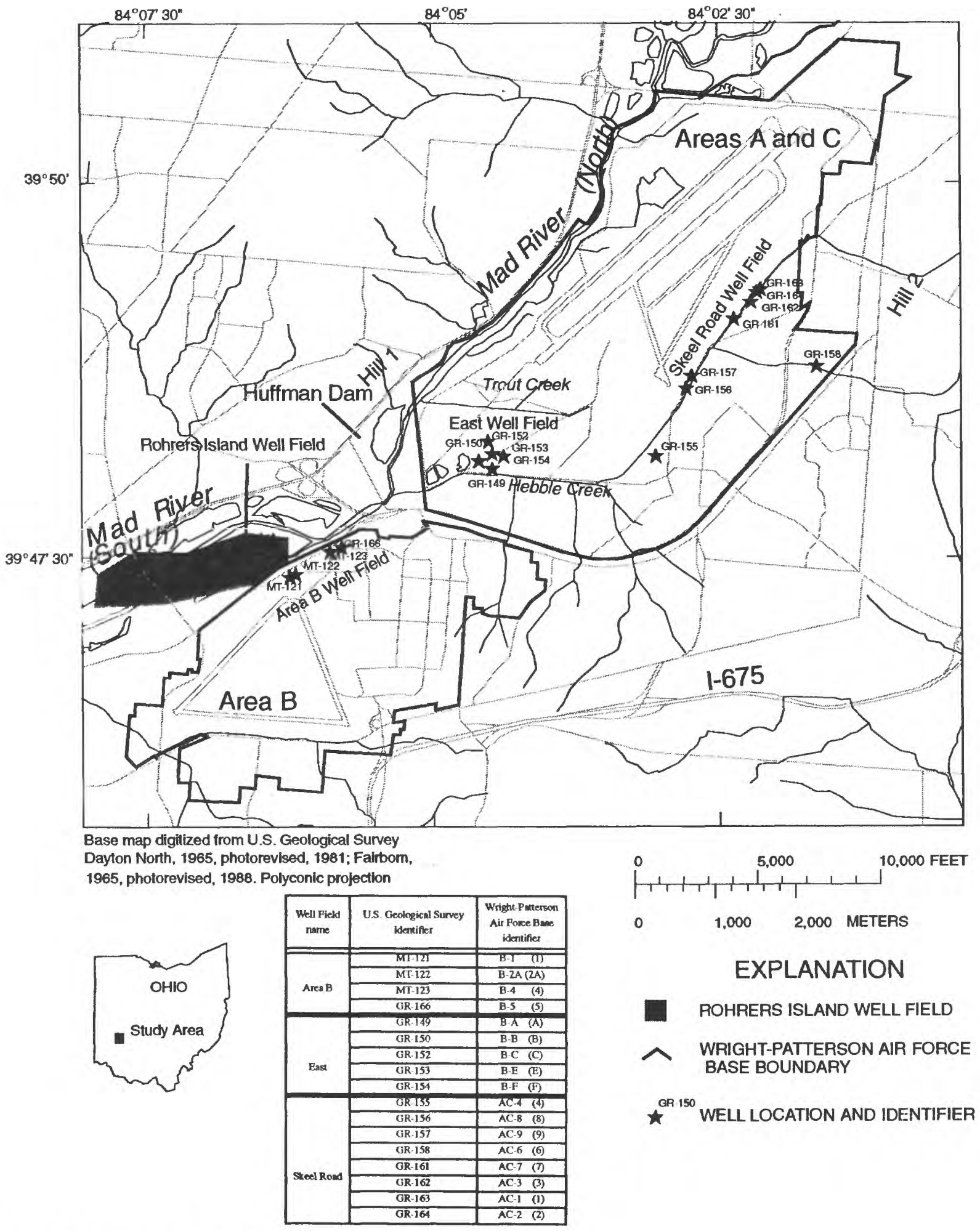

Figure 2. Location of well fields in the study area. 


\section{METHODS OF INVESTIGATION}

The computer codes used to simulate groundwater flow and levels and to generate ground-waterflow paths and traveltimes are described within this section. A geographic information system was used to calculate and display the CRA's. The theory and implementation of the ground-water-flow model and particle-tracking program are further described in separate documentation, as referenced.

\section{Numerical Modeling}

The USGS modular, finite-difference computer code, MODFLOW (McDonald and Harbaugh, 1988), was used to simulate three-dimensional, steady-state ground-water flow of an approximately $100-\mathrm{mi}^{2}$ area including the Base (fig. 1; Dumouchelle and others, 1993). MODFLOW iteratively solves the groundwater-flow equation in three dimensions by way of a block-centered, finite-difference approach. In MODFLOW, layers can be simulated as confined or unconfined or as a combination of confined and unconfined. MODFLOW can be used to simulate external stresses to the ground-water system, such as areal recharge, evapotranspiration, stream gains and losses, and pumped wells.

\section{Particle Tracking}

A particle-tracking program, MODPATH (Pollock, 1989), was used to calculate ground-water-flow paths and advective traveltimes from the hydraulic heads and flow distribution computed by MODFLOW. Advective particle tracking is based on the assumption that transport is by advection only; chemical and biological attenuation, solid-phase partitioning, dispersion, and diffusion are not considered. Traveltime and positional information are computed by use of a semianalytical particle-tracking scheme based on the assumption that the directional ground-water velocity components within a model cell vary linearly. The velocity components are based on the intercell flow rates computed by MODFLOW. Hypothetical particles of water can be tracked up or down the hydraulic gradient (backward or forward) within the computed flow field. Backward tracking can be used to track particles to their recharge locations; forward tracking enables the user to track particles to their discharge locations.

\section{Use of a Geographic Information System}

A geographic information system (GIS) consisting of mapping software integrated with a relationaldata-base management system was used to aid in delineating the CRA's. In this study, $\mathrm{ARC}^{\mathrm{INFO}}{ }^{1}$ was the GIS used to store and manipulate ground-water traveltimes and pathlines and to calculate and display the CRA's.

\section{HYDROLOGIC SETTING OF THE WRIGHT- PATTERSON AIR FORCE BASE AREA}

Topography in the study area ranges from moderately hilly in the uplands to generally flat near major rivers or streams. The major river valleys are typically broad flood plains of perennial rivers. The valleys are underlain almost everywhere by productive valley-train or alluvial aquifers. Elevations in the uplands range from 800 to $1,000 \mathrm{ft}$, and the topography is controlled by the underlying limestone and shale bedrock. Intermittent streams are common on the uplands. Detailed descriptions of geology can be found in Walton and Scudder (1960) and Norris and Spieker (1966).

The Mad River, which flows generally northeast to southwest across the study area (fig. 1), has the highest sustained dry-weather flow (relative to drainage area) in Ohio (Cross and Feulner, 1964). The Mad River also flows across a buried-valley system that contains one of Ohio's most productive aquifers-one of five in the State designated as a Sole Source Aquifer (U.S. Environmental Protection Agency, 1993).

\section{Surface-Water Flow}

The Mad River and its tributaries drain almost the entire area (fig. 1). Most of the streams in the uplands are intermittent, whereas those in the valleys are perennial. A gain/loss study by the USGS on the Mad River and its major tributaries in July 1991 (Shindel and others, 1991) indicates that the Mad River receives recharge from ground water along most of the reaches north of Huffman Dam, a flood-control structure that does not restrict normal flow (fig. 1).

\footnotetext{
${ }^{1}$ Use of trade or company names is for identification purposes only and does not constitute endorsement by the U.S. Geological Survey.
} 
South of Huffman Dam, flow in the Mad River is diverted to recharge lagoons for the city of Dayton's Rohrer's Island Well Field. Pumping from this well field also induces recharge from the lagoons to the aquifer. Ground-water levels in the area are indicative of these gains and losses.

\section{Ground-Water Flow}

The buried-valley aquifer underlying the Mad River consists of valley-train and alluvial deposits that primarily are poorly sorted sands and gravels interspersed with till units. Horizontal hydraulic conductivities range from 134 to $334 \mathrm{ft} / \mathrm{d}$ for the sands and gravels (Dumouchelle and others, 1993). Horizontal hydraulic conductivities of the till, based on permeameter and aquifer tests, range from 0.004 to $0.067 \mathrm{ft} / \mathrm{d}$ (Dumouchelle and others, 1993). The valley walls and bottom are bounded by interbedded Ordovician shales and limestones. These Ordovician rocks are virtually impermeable; horizontal hydraulic conductivities range from $10^{-5}$ to $10^{-7} \mathrm{ft} / \mathrm{d}$ based on laboratory analysis of cores, and from 0.0016 to $12 \mathrm{ft} / \mathrm{d}$ based on aquifer tests (Casey, 1992; Dumouchelle and others, 1993). The latter method results in larger estimates of hydraulic conductivity because flow to a well is dominated by fracture systems. The bedrockcontrolled uplands (fig. 3 ) bounding the valleys are underlain by a Silurian limestone aquifer that is capable of producing sufficient amounts of water for domestic supplies. Horizontal hydraulic conductivities are reported to range from $10^{-2}$ to $5 \times 10^{2} \mathrm{ft} / \mathrm{d}$ (Casey, 1992). Overlying this limestone aquifer is a generally thin layer of clay-rich, fine-grained tills that have low permeability. Hydraulic properties of these tills are likely similar to those of the tills within the sands and gravels of the buried-valley aquifer.

Ground water generally flows toward the Mad River except in areas where pumping of wells affects the natural gradient. A ground-water-level map (fig. 3) shows generalized flow directions in the upland bedrock and in the valley-train deposits (Schalk, 1992). Ground-water levels generally mimic topography; and, as expected, flow gradients are steepest in the uplands.

\section{CONTRIBUTING RECHARGE AREAS TO WATER-SUPPLY WELLS}

The area contributing recharge to a discharging well is the surface area that defines the location of the water entering the ground-water system at the water table that flows to the well and is eventually discharged from the well (Reilly and Pollock, 1993). Particles of water that reach the water table by infiltration of precipitation (recharge) and travel to a pumped well are in the CRA for that well. Figure 4 shows the relation between the contributing recharge area and the zone of contribution, which is the volumetric portion of the aquifer from which water is diverted to a pumped well (Morrissey, 1989). Most water recharging the aquifers at WPAFB consists of areal recharge (Dumouchelle and others, 1993) and as a result, the definition by Reilly and Pollock (1993) is appropriate.

CRA's can be delineated by tracking hypothetical particles of water from their recharge locations on the water table to their eventual discharge locations by use of a ground-water-flow model and a particle-tracking code. For this investigation, hydraulic heads and intercell flows output by a ground-water-flow model of the area (Dumouchelle and others, 1993) were input into the computer program MODPATH (Pollock, 1989). Ground-water-flow paths and advective traveltimes were calculated by MODPATH, which computes the average linear velocity component of flow for each active cell in the model. MODPATH also computes the principal component of the velocity vector for each cell to determine particle paths and traveltimes.

\section{Simulation of Ground-Water Flow}

A ground-water-flow model calibrated to steady-state ground-water-flow conditions of September-October 1987 was developed by Dumouchelle and others (1993) for the area including the Base. The purpose of the model was, in part, to determine and evaluate sources and sinks of regional ground-water flow. These sources and sinks included the Mad River and its tributaries because surfacewater/ground-water relations need to be understood in this type of hydrogeologic setting.

The model grid used for the flow model is shown in figure 5; grid cell dimensions were 500, 750 or $1,000 \mathrm{ft}$ on a side; the smallest cell dimensions are in the area around Huffman Dam. The model consists 


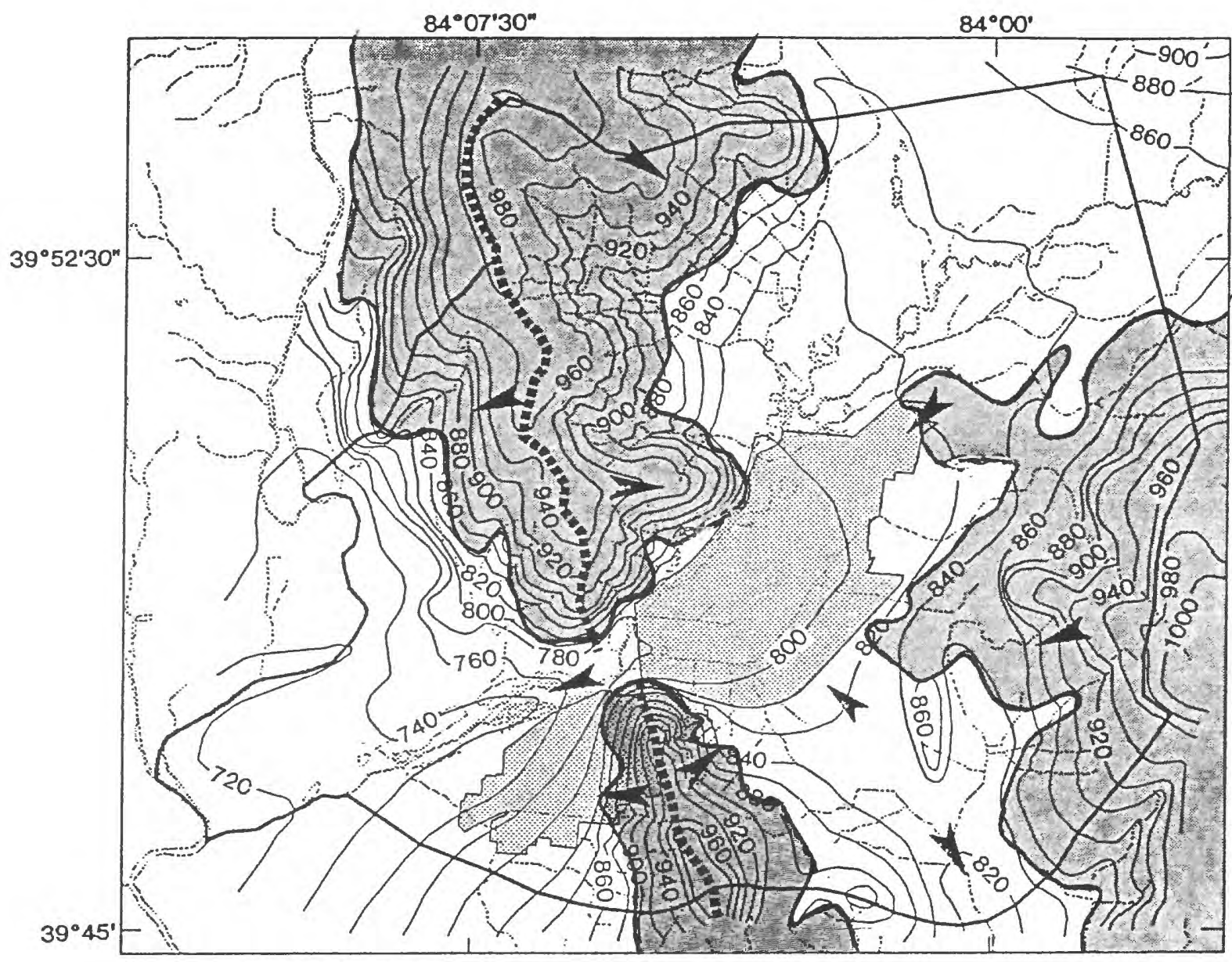

Base map digitized from U.S. Geological Survey Bellbrook. 1965. photorevised 1987; Dayton North. 1965, photorevised 1981: Dayton South, 1966. photorevised 1981: Donnelsville. 1965. photorevised 1973 photoinspected 1983.

Fairborn. 1965. photorevised 1988: New Carlisle. Fairborn. 1965. photorevised 1988. photoinspected 1984; Tipp City, 1965. photorevised 1982: Xenia. 1965, photorevised 1987: Yellow Sorings, 1968, photorevised 1975. Polyconic projection

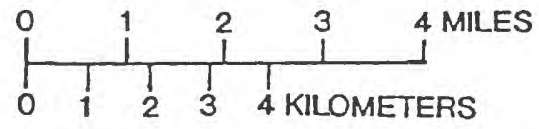

\section{EXPLANATION}

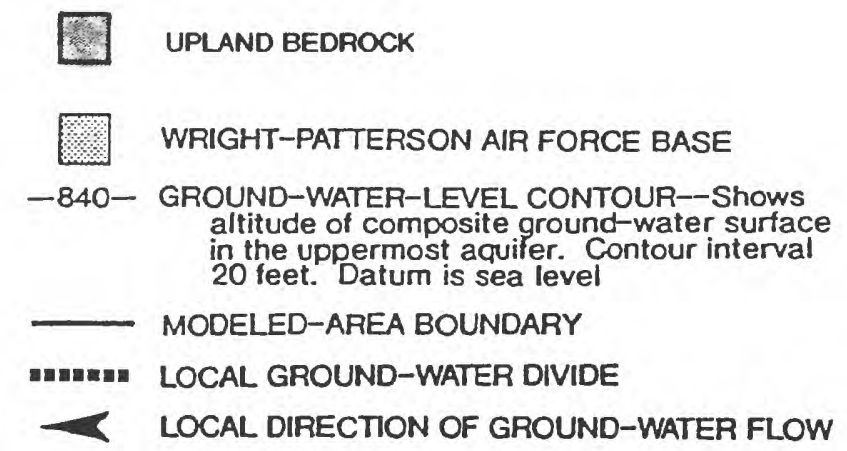

Figure 3. Ground-water levels and generalized flow directions in the upland bedrock and valley-train deposits. (From Dumouchelle and others, 1993, fig. 11.) 

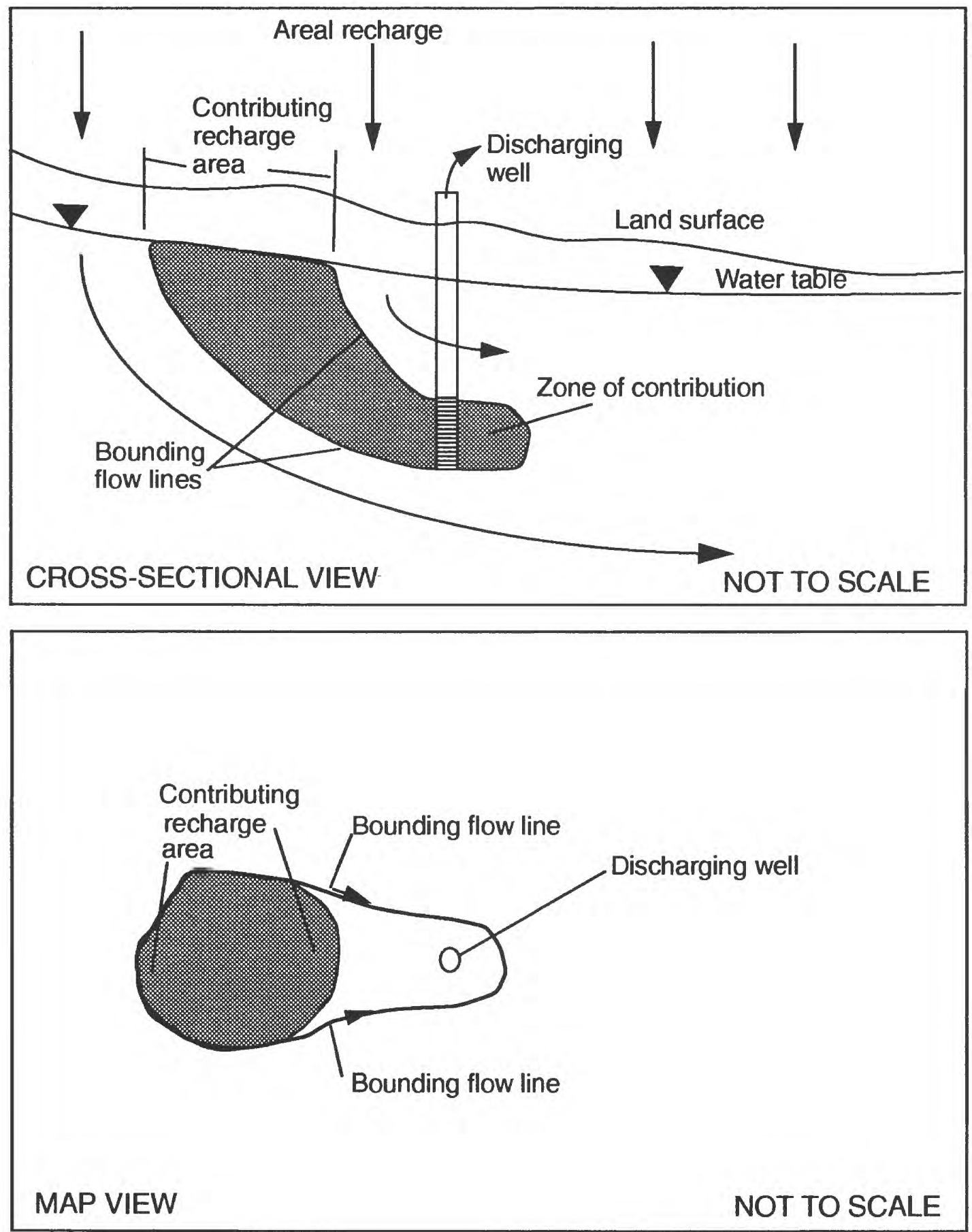

Figure 4. Contributing recharge area to a single discharging well in a simplified hypothetical ground-waterflow system. (Modified from Reilly and Pollock, 1993, fig. 1.) 


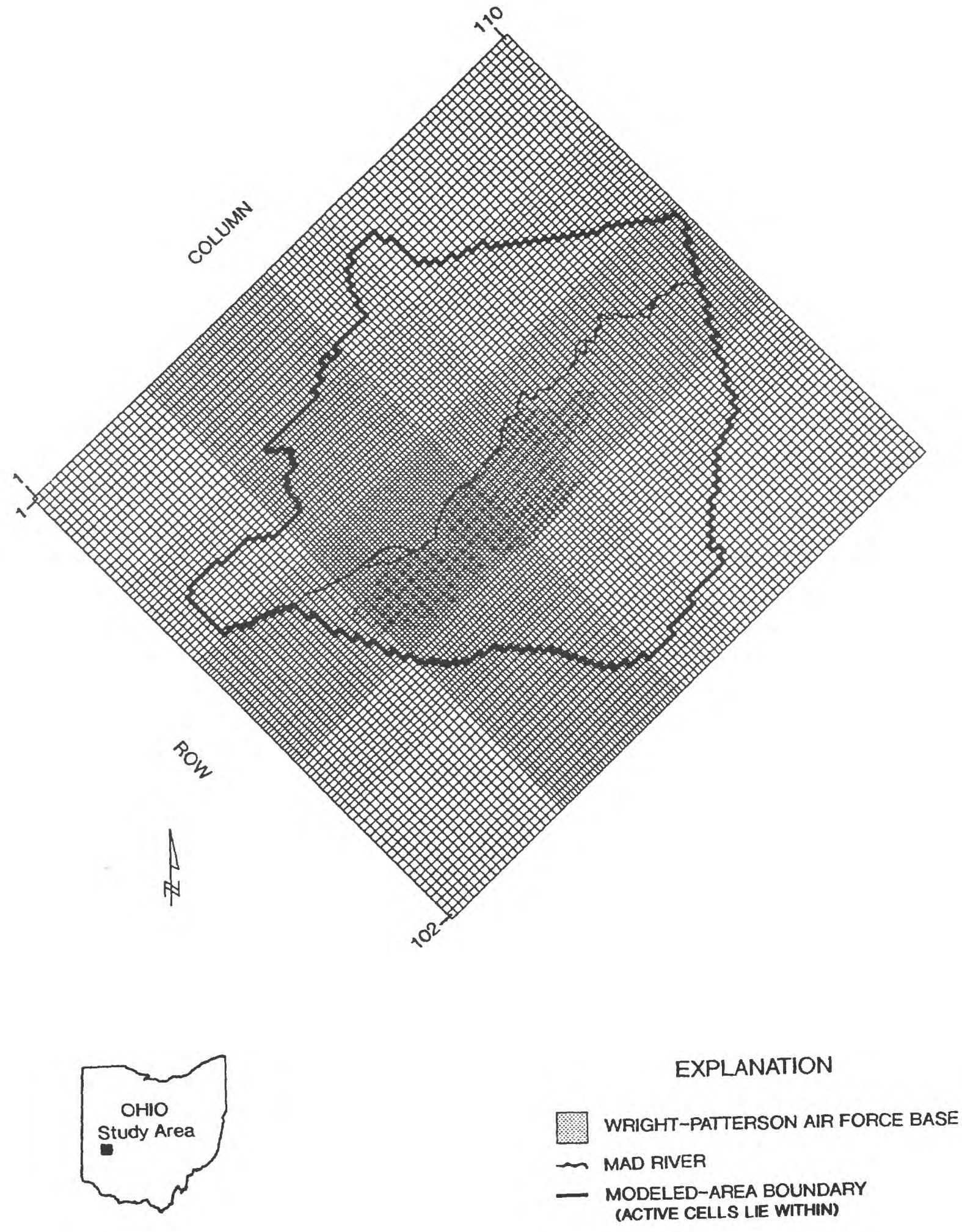

Figure 5. Model grid in relation to modeled area. (From Dumouchelle and others, 1993, fig. 19.) 


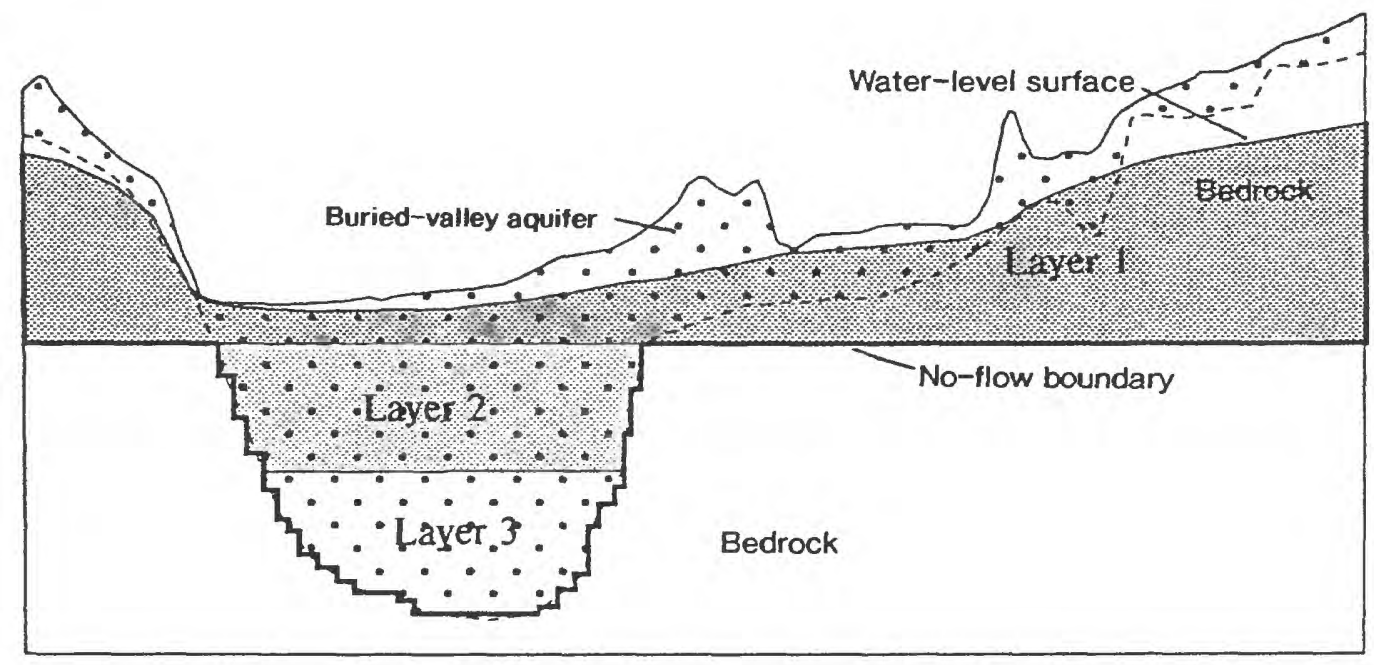

Figure 6. Generalized sectional view of the ground-water-flow model, Wright-Patterson Air Force Base, Ohio. (From Dumouchelle and others, 1993, fig. 21.)

of three layers, as can be seen in the sectional view of the model shown in figure 6 . Layer 1 , the uppermost layer, ranges in 1 hickness from 20 to $200 \mathrm{ft}$ and simulates flow in the uppermost part of the buricd-valley aquifer and the entire permeable thickness of upland bedrock aquifer. The base of the uppermost part of the buried-valley aquifer is characterized by the presence of discontinuous deposits of poorly permeable clays and silts. Layer 2 of the model simulates the central part of the buried-valley aquifer, in which most of the water-supply wells are completed. Layer 3 of the model simulates the part of buried-valley aquifer that is bounded by the bottom of layer 2 and the Ordovician bedrock at the bottom of the valley. The boundary between layers 2 and 3 generally corresponds to a discontinuous till unit. Lateral boundaries to groundwater flow were based on ground-water divides, surface-water bodies, and calculated flux through valley cross-sections. A complete description of the groundwater-flow model can be found in Dumouchelle and others (1993). Because the model and its results are used to delineate the CRA's described in this report, a brief discussion of the input parameters and sensitivity analyses is given here.

\section{Input Parameters}

Layer 1 of the model was simulated as an unconfined aquifer. Horizontal hydraulic conductivities $\left(\mathrm{K}_{1 \mathrm{~h}}\right)$ in the areas containing upland bedrock in the model generally ranged from 0.2 to $1 \mathrm{ft} / \mathrm{d}$. In the uppermost buried-valley aquifer, $K_{1 \mathrm{~h}}$ values of 5 to $210 \mathrm{ft} / \mathrm{d}$ were assigned on the basis of aquifer-test data and calibration of the model. A transitional zone of intermediate $\mathrm{K}_{1 \mathrm{~h}}$ was used along the valley walls because of the presence of clay-rich sediments draping the valley walls; in addition, use of an intermediate $\mathrm{K}_{1 \mathrm{~h}}$ allows for a smooth transition between upland and valley hydraulic conductivities. 
Layers 2 and 3, present only in the bedrock valleys, were modeled as confined aquifers. Transmissivities $\left(\mathrm{T}_{2}\right.$ and $\left.\mathrm{T}_{3}\right)$ ranged from 4 to $76,600 \mathrm{ft}^{2} / \mathrm{d}$ and also were based on aquifer-test data and refined with model calibration. Transmissivities in the central parts of the valleys were higher than on the flanks of the valleys. Vertical leakance between layers one and two $\left(V_{1}\right)$ and between layers 2 and $3\left(\mathrm{~V}_{2}\right)$ was used to simulate the discontinuous till units.

Areal recharge to the ground-water-flow system from precipitation was distributed to the uppermost active nodes in the model. Recharge rates ranged from 1 to $6 \mathrm{in} / \mathrm{yr}$ in the uplands and from 6 to $15 \mathrm{in} / \mathrm{yr}$ in the valleys and were based on previous studies, surficial geology, and recession-curve analysis.

Pumping rates for the period of calibration were obtained for all pumping centers producing greater than approximately $10 \mathrm{gal} / \mathrm{min}$. Primarily, these centers are in industrial areas, in or near municipalities, and on the Base. The city of Dayton's Rohrer's Island Well Field (fig. 2) was the largest pumping center included in the model; withdrawals were approximately $50 \mathrm{Mgal} / \mathrm{d}$. For the steady-state calibration of the model, Skeel Road and East Well Fields were pumping at 1.9 and $1.1 \mathrm{Mgal} / \mathrm{d}$, respectively. Area $\mathrm{B}$ wells were not active for the time period used for the calibration.

Perennial streams in the area were modeled as such, and streambed conductances $\left(\mathrm{K}_{\text {riv }}\right)$ were based on seepage-meter measurements for the Mad River and Hebble Creek. Intermittent streams, present primarily in the uplands, were modeled as drains.

\section{Calibration Targets}

Ground-water levels at 330 wells, measured in late 1987, were compared with simulated heads during the steady-state calibration process. Measured gains to and losses from streams in the area were also compared to simulated gains and losses. Vertical hydraulic gradients between shallow, intermediate, and deep well clusters completed in the valley fill also were used during calibration to refine the vertical groundwater-flow component. Previous estimates of groundwater flow from the upland bedrock to the valley-train were also used qualitatively during calibration.

\section{Sensitivity Analyses}

Systematic changes in aquifer parameters input to the ground-water-flow model were made by
Dumouchelle and others (1993) to ascertain the sensitivity of the model to these parameters. Because the uncertainty of the size and shape of the CRA's is related to the sensitivity of the model to input parameters, a discussion of model sensitivity to input parameters affecting CRA's is necessary here. The sensitivity analysis presented here and in Dumouchelle and others (1993) is supplemented by an uncertainty analysis of the CRA's, described later in this report.

The input parameters that were varied during the sensitivity analysis were horizontal hydraulic conductivity of layer $1\left(\mathrm{~K}_{1 \mathrm{~h}}\right)$, vertical leakance between layers 1 and $2\left(\mathrm{~V}_{1}\right)$, vertical leakance between layers 2 and $3\left(\mathrm{~V}_{2}\right)$, transmissivity of layer $2\left(\mathrm{~T}_{2}\right)$, transmissivity of layer $3\left(\mathrm{~T}_{3}\right)$, areal recharge to the aquifers $(\mathrm{RCH})$, and riverbed conductance $\left(\mathrm{K}_{\text {riv }}\right)$. The responses of hydraulic heads in the uplands and buried valleys, Mad River and tributary discharges, and flows from the upland bedrock and under Huffman Dam were examined during sensitivity analyses in relation to input-parameter variation. These outputs from the model may affect the size and shape of the CRA's for the Skeel Road and Area B Well Fields.

Simulated hydraulic heads were most sensitive to changes in $\mathrm{K}_{1 \mathrm{~h}}$ in the uplands and in the valley-train deposits. Multiplying $\mathrm{K}_{1 \mathrm{~h}}$ of the uplands by 0.1 resulted in an 800-percent increase in the root-meansquare error of head residuals. Multiplying $\mathrm{K}_{1 \mathrm{~h}}$ of the valley-train deposits by 0.1 caused a 500 -percent increase in the root-mean-square error of head residuals. Head residuals also are affected significantly by decreases to $K_{\text {riv }}$ and $V_{1}$. These relations are shown in figure 7 . The changes in $\mathrm{K}_{1 \mathrm{~h}}$ also affected the intercell flows calculated by the model. The intercell flows were somewhat sensitive to positive changes in upland $\mathrm{K}_{1 \mathrm{~h}}$, negative changes in $\mathrm{V}_{1}$, and any changes to areal recharge of the valley-train deposits.

Dumouchelle and others (1993) described specific stream reaches and valley segments along which discharges and fluxes were analyzed: Hebble Creek, Mad River North and South, Trout Creck, Hills 1 and 2, and Huffman Dam (fig. 2). A discussion of model sensitivity to simulated discharges in Mad River South and Hebble Creek is necessary here because the Mad River is adjacent to the Area B wells, and Hebble Creek is adjacent to the Skeel Road and East Well Fields. Surface-water inputs from Mad River South and Hebble Creek to these well fields could affect their CRA's. 

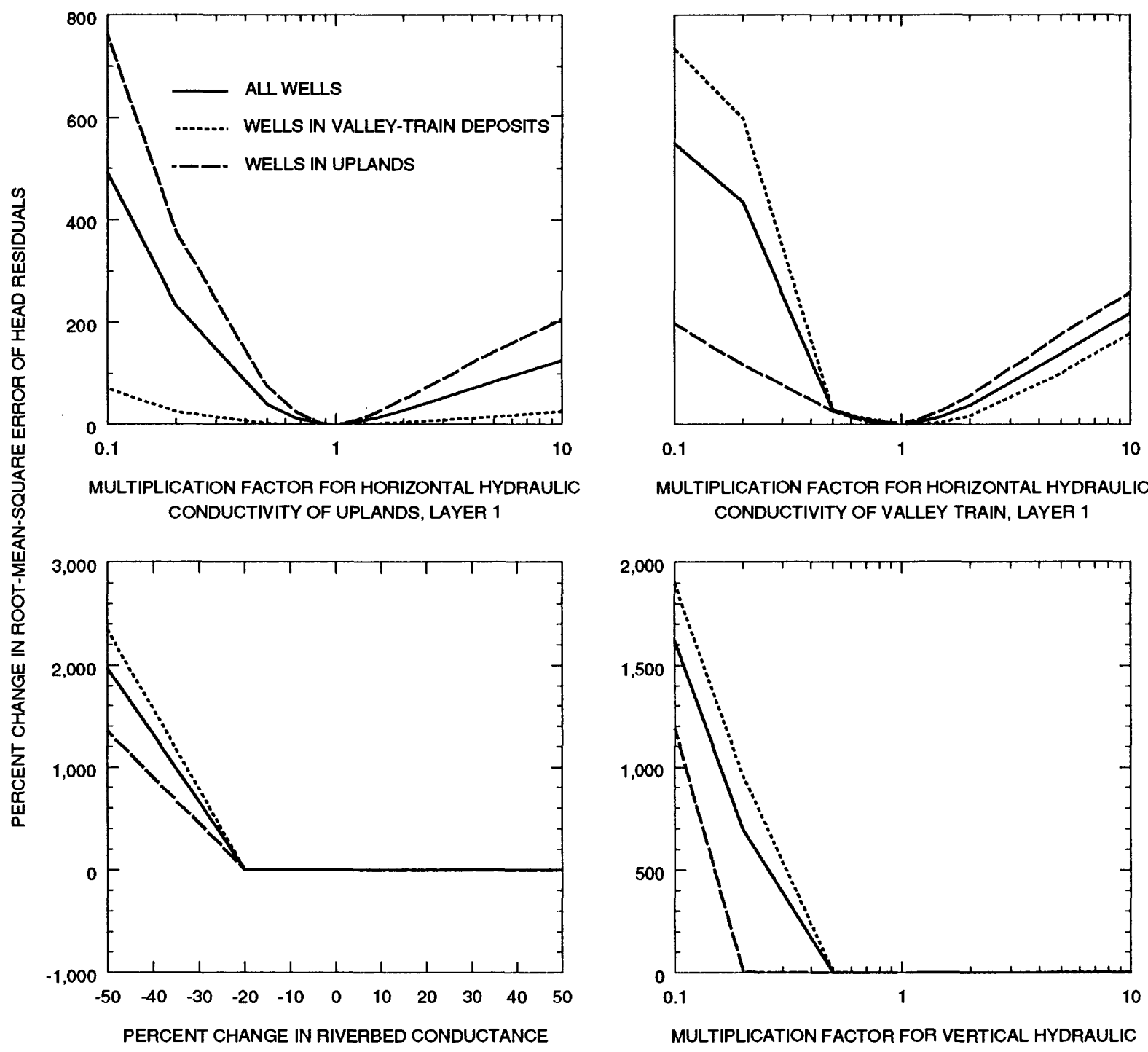

MULTIPLICATION FACTOR FOR HORIZONTAL HYDRAULIC CONDUCTIVITY OF VALLEY TRAIN, LAYER 1

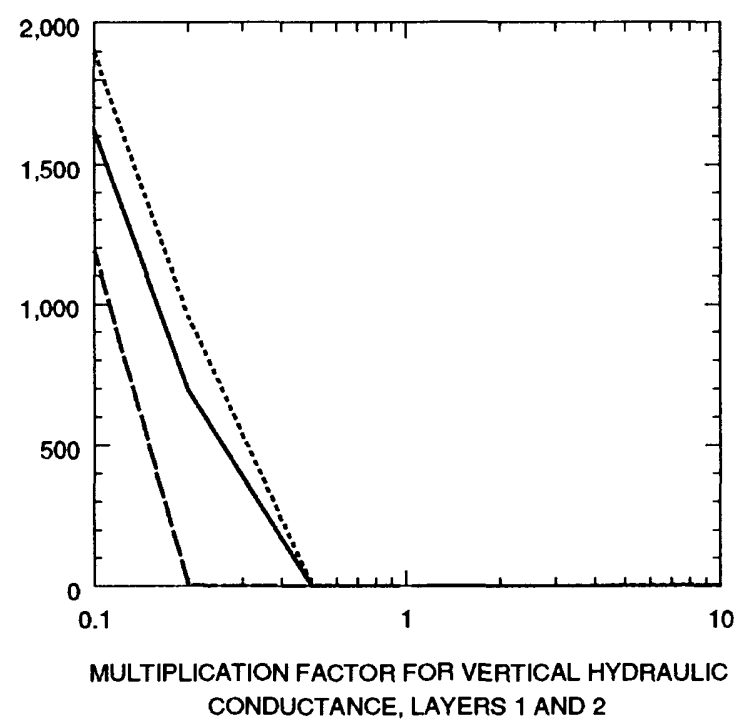

Figure 7. Sensitivity of simulated heads to changes in horizontal hydraulic conductivity, riverbed conductance, and vertical hydraulic conductance in model of ground-water-flow system, Wright-Patterson Air Force Base, Ohio, and vicinity. (Modified from Dumouchelle and others, 1993, fig. 34.) 
Hebble Creek flows through an underground pipe and a concrete channel in the reach adjacent to Skeel Road Well Field, thereby preventing significant surface-water influence on well production. Results of sensitivity analyses of various hydraulic parameters and the effects of changes in these parameters to discharges in Mad River South and Hebble Crcek are shown in figure 8 . The most significant effects are seen when the vertical conductance between layers 1 and 2 is decreased, simulating a less permeable confining unit between these layers. The sensitivity analyses also show that variations in areal recharge also will significantly affect the simulated discharges to Hebble Creek.

The effects of flow from Hills 1 and 2 also are important because of the proximity of these hills to the East and Skeel Road Well Fields, respectively. The results of sensitivity analyses of the selected discharges and fluxes are shown in figure 9. Variations in areal recharge to the upland areas and in the horizontal hydraulic conductivity of the upland areas have the most significant effect on flows from Hills 1 and 2 . Changes in ground-water flows under Huffman Dam are important to the CRA's of the Area B Well Field. Changes in $\mathrm{T}_{2}$ have almost a one-10-one relation to changes in flow under Huffman Dam (fig. 10). Variations in $V_{1}$ also significantly affect flows under Huffman Dam (fig. 10).

\section{Limitations of Flow Model}

A ground-water-flow model is a numerical representation of a ground-water-flow system and, as such, has limitations. These limitations can be a result of the code used to solve the ground-water-flow equation, the hydrologic data available for inclusion in defining boundary conditions or calibration, or the scale at which the model is used. Numerical approximations and convergence criteria used in the code for solving the ground-water-flow equations may affect how well the model reflects the ground-water-flow system. Uncertainty in physical measurements used to calibrate the model, such as streamflow measurements or well pumpage, can lead to uncertainty in how well the model is calibrated. The model by Dumouchelle and others (1993) was developed to examine regional ground-water flow; more localized flow was not examined in their analyses. These and other limitations of the ground-water-flow model have direct bearing on the simulations of the contributing recharge areas and are examined later with the limitations of the particle- tracking analyses. The limitations of the groundwater-flow model are discussed in detail in Dumouchelle and others (1993).

\section{Delineation by Particle Tracking}

Hydraulic heads and intercell flows output from the previously described model (Dumouchelle and others, 1993) were input to the computer program MODPATH to determine CRA's as a function of pumping rate and porosity. Four hypothetical particles of water were placed on the water table in each grid cell and tracked to their eventual discharge points; the trajectories of particles that discharged to wells in Base well fields were saved with the traveltime information. The particle paths, as well as traveltimes, were input into ARC/INFO, and initial particle locations with traveltimes from 0 to 1,1 to 5 , and 5 to 10 years (1-, 5-, and 10- years) were grouped to create 1-, 5 and 10-year CRA's for normal, intermediate, and maximum pumping rates.

The CRA's to the Skeel Road and East Well Fields, under October-December 1987 steady-state conditions are shown in figure 11. Records of pumping rates were averaged for October-December 1987 and are approximately 1.9 and $1.1 \mathrm{Mgal} / \mathrm{d}$ for Skeel Road and East Well Fields, respectively. Because of waterquality concerns (Linda Rogers, Wright-Patterson Air Force Base, oral comm., 1993), the East Well Field has been unused since late in 1987.

The description of the CRA's that follows concentrates on the Skeel Road and Area B Well Fields. However, because the East Well Field may be used in the future for water supply, the East Well Field is accounted for in describing variations in CRA's in response to pumping.

Normal, intermediate, and maximum-capacity pumping rates were input into the ground-water-flow model by Dumouchelle and others (1993) in a series of predictive simulations. Normal pumping rates were determined from average pumping at each well field over a period of time, and the maximum pumping capacity of each well was defined with reference to well and aquifer-test information. Maximum-capacity data were compiled to compute a worst-case scenario of the CRA's. The average of normal and maximum pumping (intermediate) was also used in the analysis to refine the range of pumping conditions. Porosities, which are required by the particle-tracking code, were estimated from specific yields derived from aquifer 

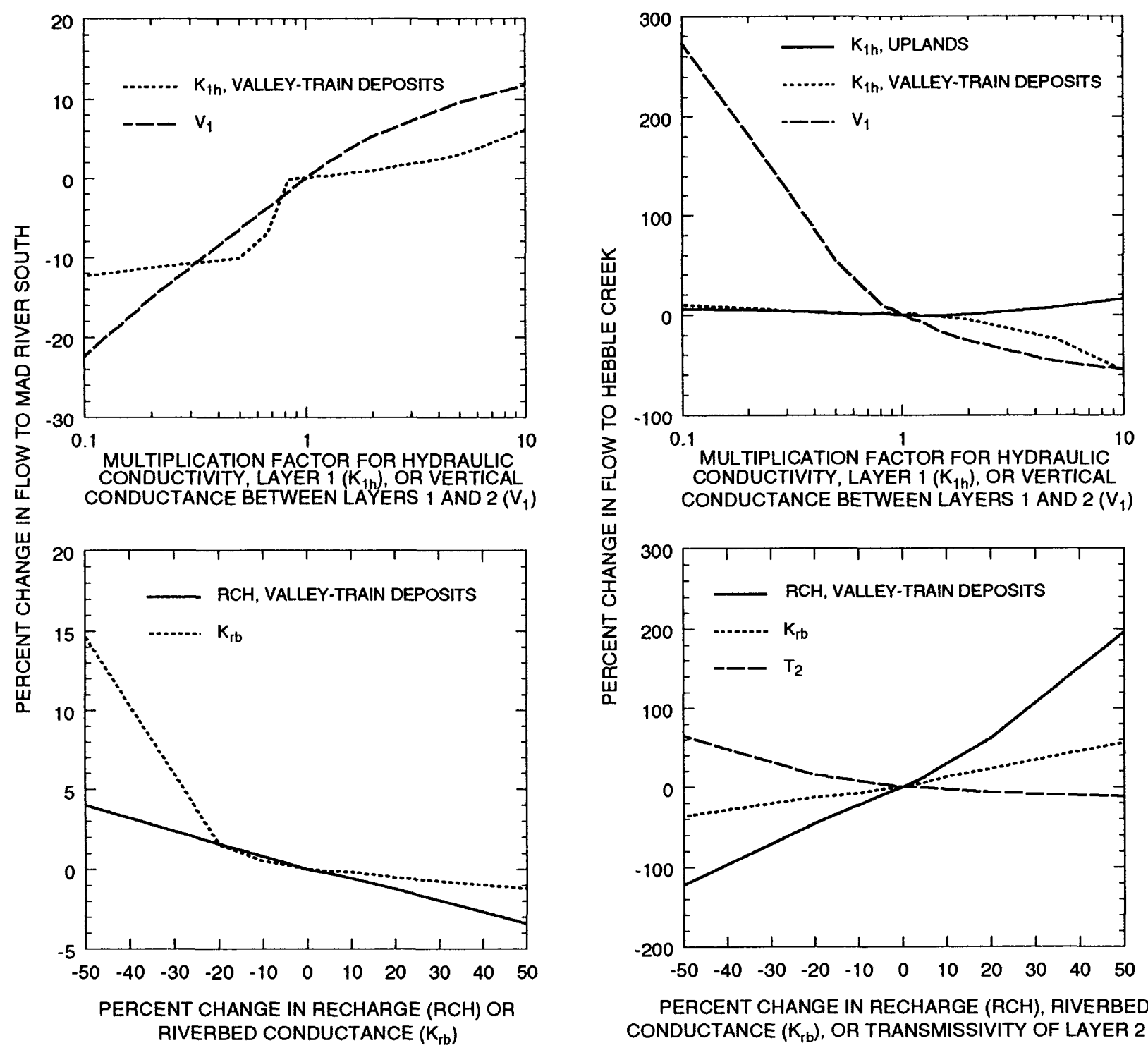

PERCENT CHANGE IN RECHARGE (RCH), RIVERBED CONDUCTANCE $\left(K_{\mathrm{rb}}\right)$, OR TRANSMISSIVITY OF LAYER $2\left(T_{2}\right)$

Figure 8. Sensitivity of simulated flows to Mad River South and Hebble Creek to changes in hydrogeologic parameters in the model of the ground-water-flow system, Wright-Patterson Air Force Base, Ohio. (Modified from Dumouchelle and others, 1993, figs. 37-38.) 

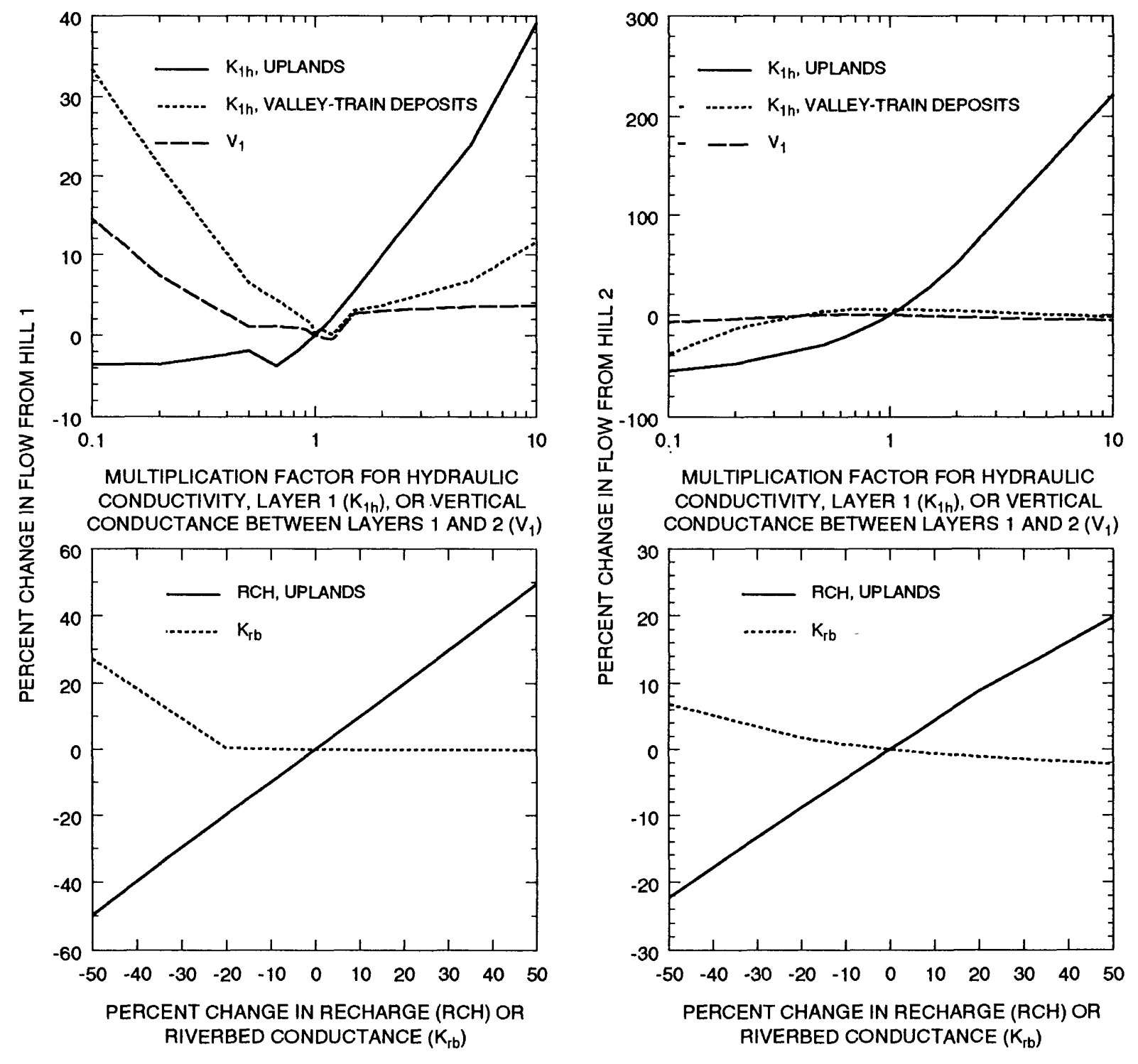

Figure 9. Sensitivity of simulated flows from Hills 1 and 2 to changes in hydrogeologic parameters in the model of the ground-water-flow system, Wright-Patterson Air Force Base, Ohio. (Modified from Dumouchelle and others, 1993, fig. 36.) 


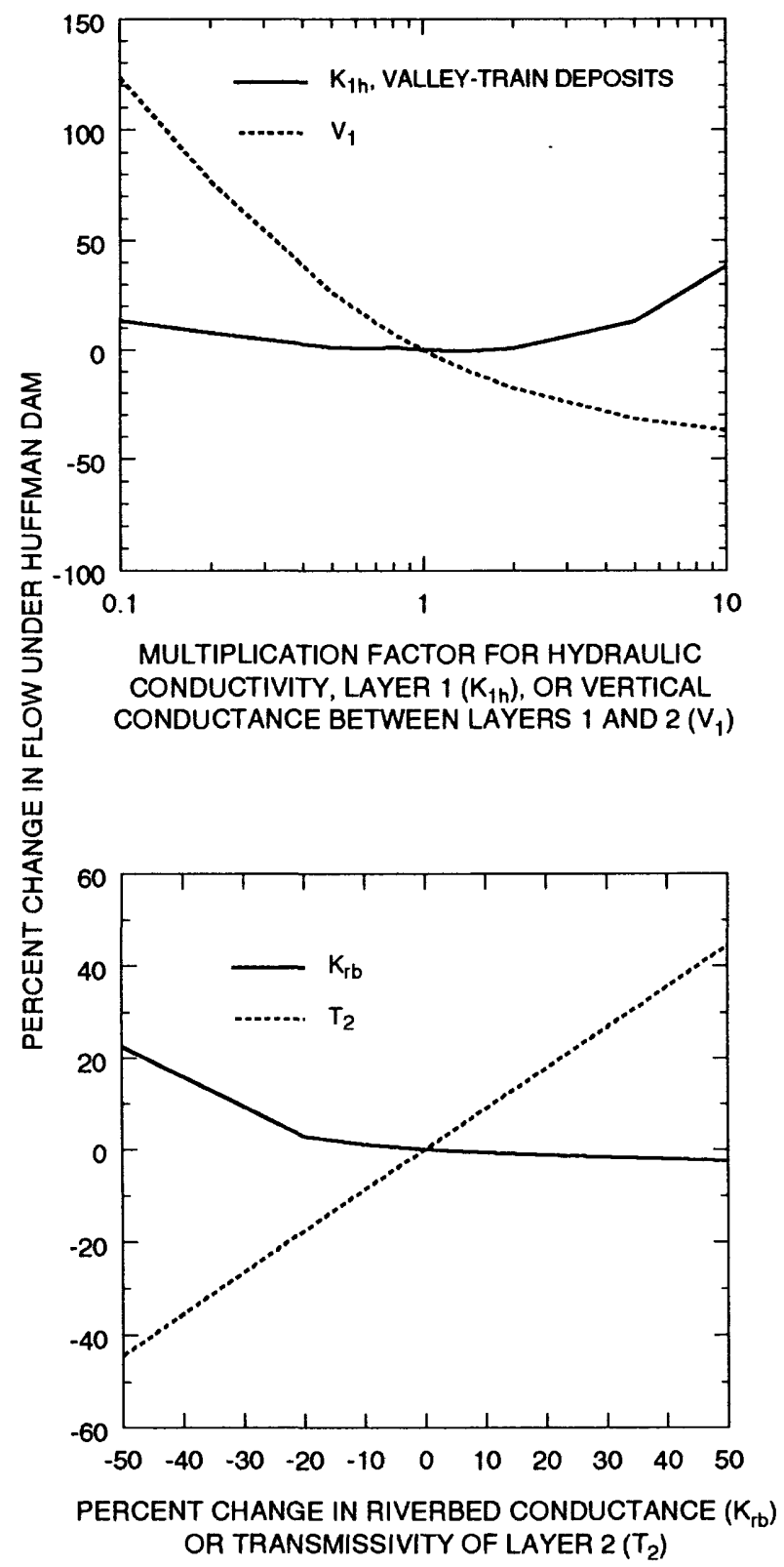

Figure 10. Sensitivity of simulated flows under Huffman Dam to changes in hydrogeologic parameters in the model of the ground-water-flow system, Wright-Patterson Air Force Base, Ohio. (Modified from Dumouchelle and others, 1993, figs. 37-38.) 


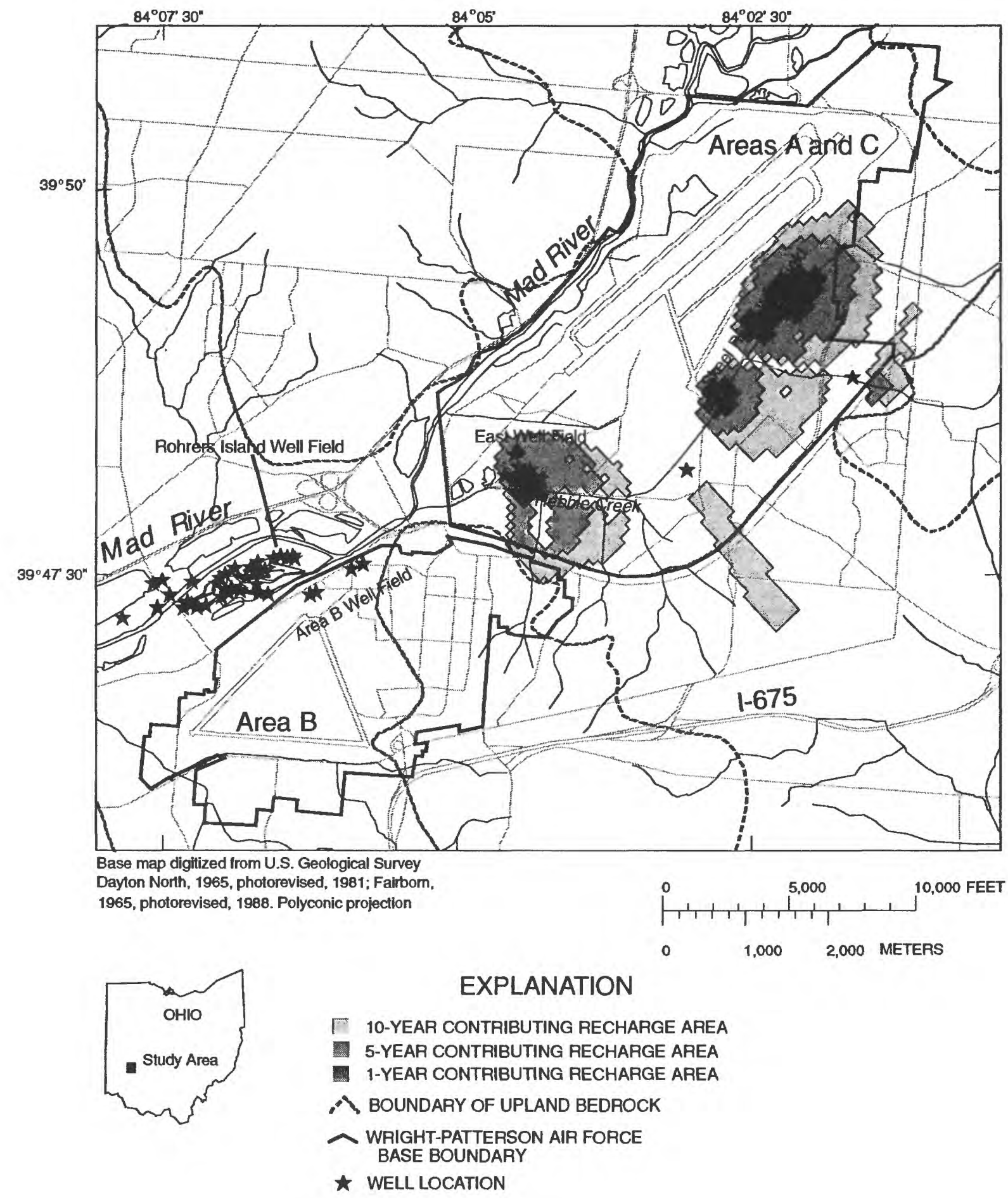

Figure 11. One-, 5-, and 10-year contributing recharge areas to the Skeel Road and East Well Fields (Pumping rates for the well fields are based on October-December 1987 conditions). 
test data in the area (Johnson, 1967). The assigned porosities are $0.20,0.25$, and 0.15 for layers 1,2 , and 3 of the ground-water-flow model, respectively. The sensitivity of variations in porosity is examined later in this report.

The previously described ground-water-flow model (Dumouchelle and others, 1993) was modified to incorporate pumping at the Area B Well Field. Increased pumping in this area caused a numerical instability in the model (resulting in dry model cells) near the boundary of the upland bedrock and valleytrain deposits. This instability was resolved with a minor lowering of the bottom of layer 1 and slightly increasing recharge rates along this boundary. Hydraulic heads and intercell flows predicted by the modified model were compared with those of the original model, and differences in model results are small. For example, the overall water budget shows differences of less than 0.1 percent, and the root-mean-squared error of head residuals in the modified model differs by less than 1 percent from that of the original model. The modified model was used for all CRA analyses.

The yearly average pumping rate for October 1986 through November 1987 , was $1.9 \mathrm{Mgal} / \mathrm{d}$ for Skeel Road Well Field; this rate is assumed, for simulation purposes, to be the normal pumping rate for these wells. The maximum capacity of the wells that make up the Skeel Road Well Field is approximately 6.3 Mgal/d. Pumping data from July 1989 to March 1990 for the Area B Well Field indicate an assumed normal pumping rate of approximately $1.7 \mathrm{Mgal} / \mathrm{d}$. Maximum capacity of the wells in the Area B Well Field is approximately $4.6 \mathrm{Mgal} / \mathrm{d}$. For all simulations including Area B and Skeel Road Well Fields, the East Well Field is not pumping.

The traveltime-delineated CRA's for the Skeel Road and Area B Well Fields, under normal, intermediate, and maximum pumping, are shown in figures 12 through 14. The pumping rates used for these simulations and the resulting size of the CRA's for the Base well fields are given in table 1. Figure 15 illustrates the nearly linear relation between the size of the CRA's and pumping rates.
Table 1. Pumping rates and contributing recharge areas to well fields at Wright-Patterson Air Force Base, Ohio

[Mgal/d, million gallons per day; mi $^{2}$, square miles; Normal pumping for Skeel Road and East Well Fields based on October-December 1987 averages; normal pumping for Area B Well Field based on July 1989-March 1990 averages. Maximum pumping is maximum capacity of the well field, based on well-test data. Intermediate pumping is midway between normal and maximum.

\begin{tabular}{|c|c|c|c|c|}
\hline \multicolumn{2}{|c|}{ Pumping } & \multirow{2}{*}{\multicolumn{3}{|c|}{$\begin{array}{l}\text { Contributing recharge areas } \\
\qquad\left(\mathrm{mi}^{2}\right)\end{array}$}} \\
\hline \multirow{2}{*}{$\begin{array}{l}\text { Condi- } \\
\text { tion }\end{array}$} & \multirow{2}{*}{$\begin{array}{c}\text { Rate } \\
\text { (Mgal/d) }\end{array}$} & & & \\
\hline & & 1-year & 5-year & 10-year \\
\hline \multicolumn{5}{|c|}{ Skeel Road Well Field } \\
\hline Normal & 1.9 & 0.33 & 0.89 & 1.78 \\
\hline Intermediate & 4.1 & .44 & 1.15 & 2.46 \\
\hline Maximum & 6.3 & .51 & 1.45 & 3.24 \\
\hline \multicolumn{5}{|c|}{ Area B Well Field } \\
\hline Normal & 1.7 & 0.038 & 0.201 & 0.343 \\
\hline Intermediate & 3.2 & .047 & .357 & .549 \\
\hline Maximum & 4.6 & .065 & .502 & .863 \\
\hline \multicolumn{5}{|c|}{ East Well Field } \\
\hline Normal & 1.1 & 0.056 & 0.428 & 0.694 \\
\hline Intermediate & 3.7 & .283 & .968 & 1.492 \\
\hline Maximum & 6.2 & .241 & 1.218 & 2.449 \\
\hline
\end{tabular}

The CRA's for the Skeel Road Well Field are generally oval, extending to the north and east (up the Mad River valley) for the northernmost wells and to the south and east for the southerm wells in the well field (fig. 12). As pumping rates increase, the CRA's for the northernmost wells extend further upvalley and toward a losing reach of Mad River. The Skeel Road CRA's are not affected appreciably by surface-water sources. Hebble Creek in the reach near the wells is in a concrete channel, and this reach was not simulated in the model. The shape of the CRA's for the wells is generally typical of wells placed in a homogeneous, isotropic unconfined aquifer in a uniform regional velocity field. Wells further to the south are more affected by ground-water flow entering the Mad River valley from the upland area to the east and from a tributary buried valley oriented approximately northwestsoutheast (fig. 3).

The smaller size of the CRA's for the Area B Well Field is primarily the result of high rates of induced infiltration from the Mad River, the effects of the nearby well field at Rohrer's Island, and the bedrock hill in the northeast part of Area B (fig. 3). As stated before, the pumping rate at the Rohrer's Island Well Field is approximately $50 \mathrm{Mgal} / \mathrm{d}$. Pumping at Rohrer's Island Well Field and the upland area to the south and east of Area B Well Field restricts the CRA's to the Mad River Valley and the tributary valley. As pumping rates increase at the Area $\mathrm{B}$ Well Field, the CRA increases in size to the northeast, up the Mad 


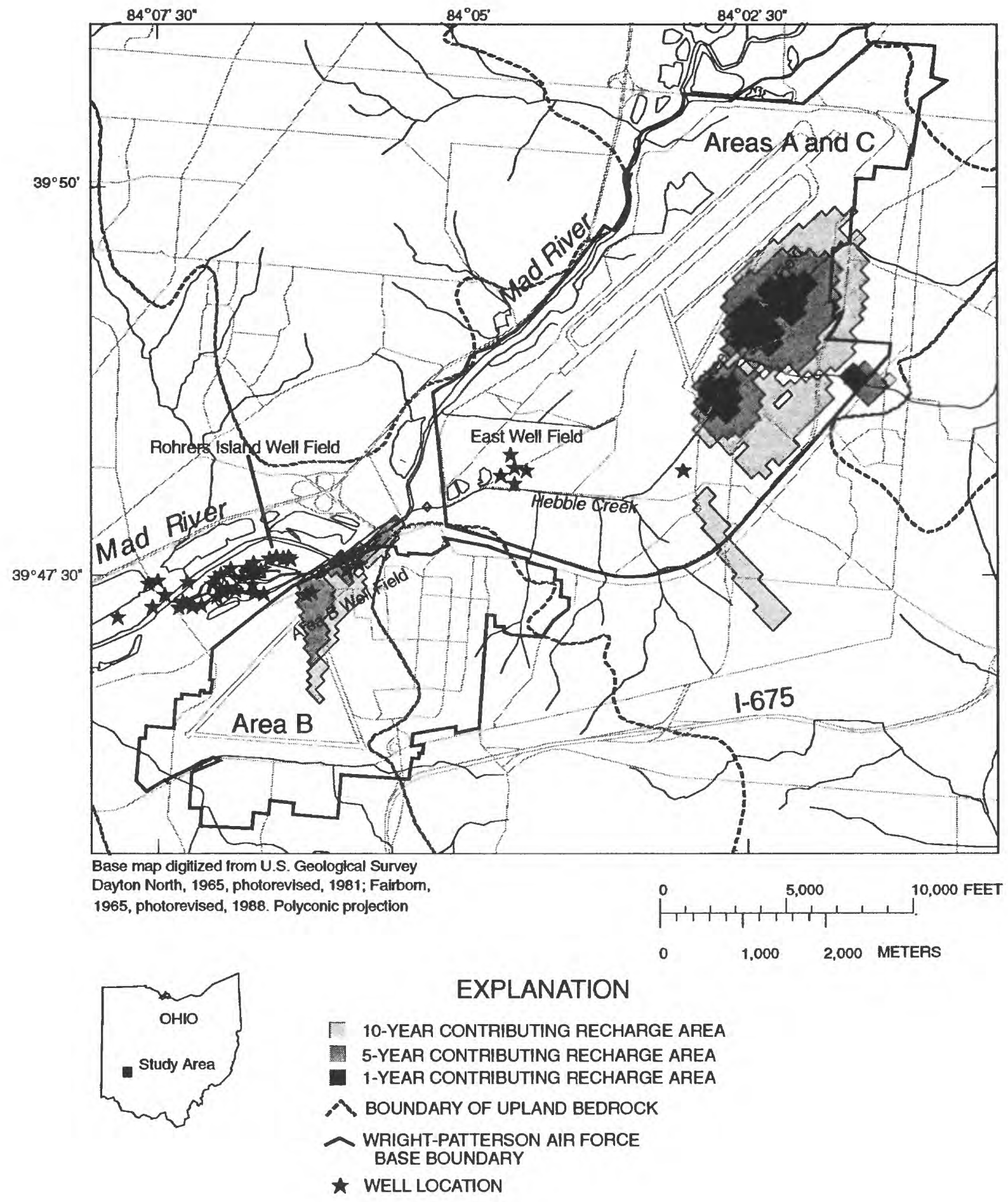

Figure 12. Contributing recharge areas to Skeel Road and Area B Well Fields under normal pumping conditions (1.9 and 1.7 million gallons per day, respectively). 


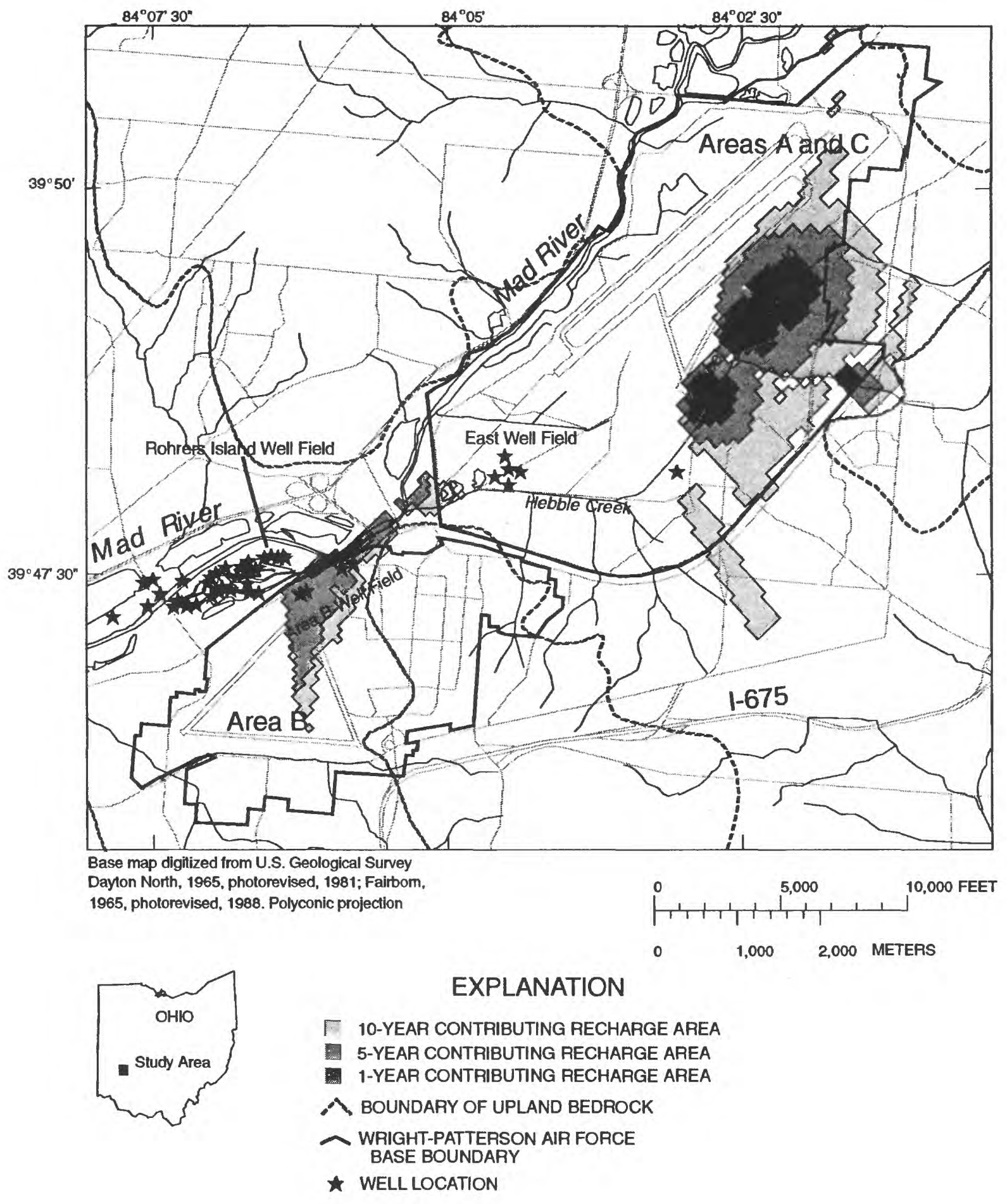

Figure 13. Contributing recharge areas to Skeel Road and Area B Well Fields under intermediate pumping conditions (4.1 and 3.2 million gallons per day, respectively). 


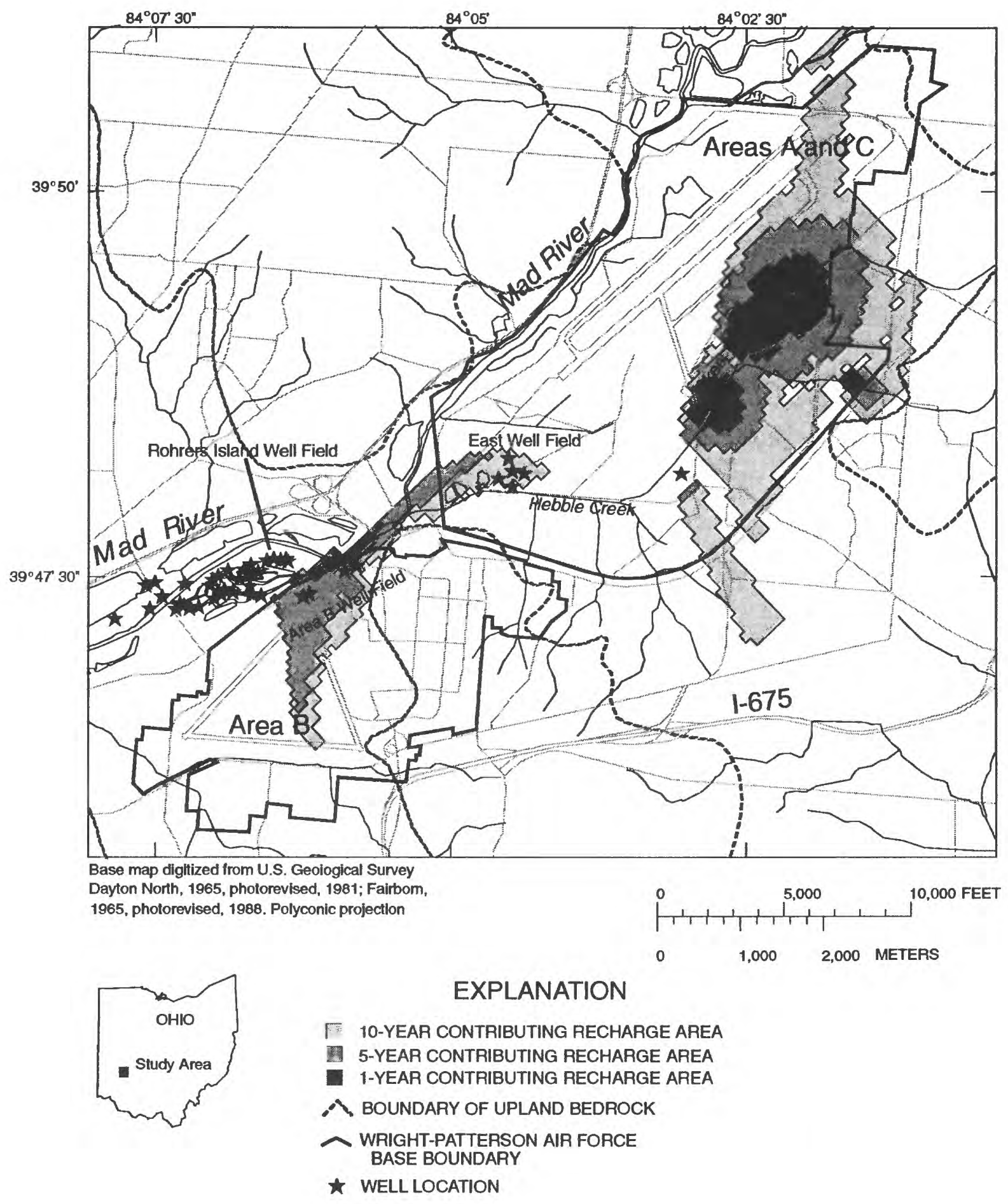

Figure 14. Contributing recharge areas to Skeel Road and Area B Well Fields under maximum capacity pumping conditions (6.3 and 4.6 million gallons per day, respectively). 


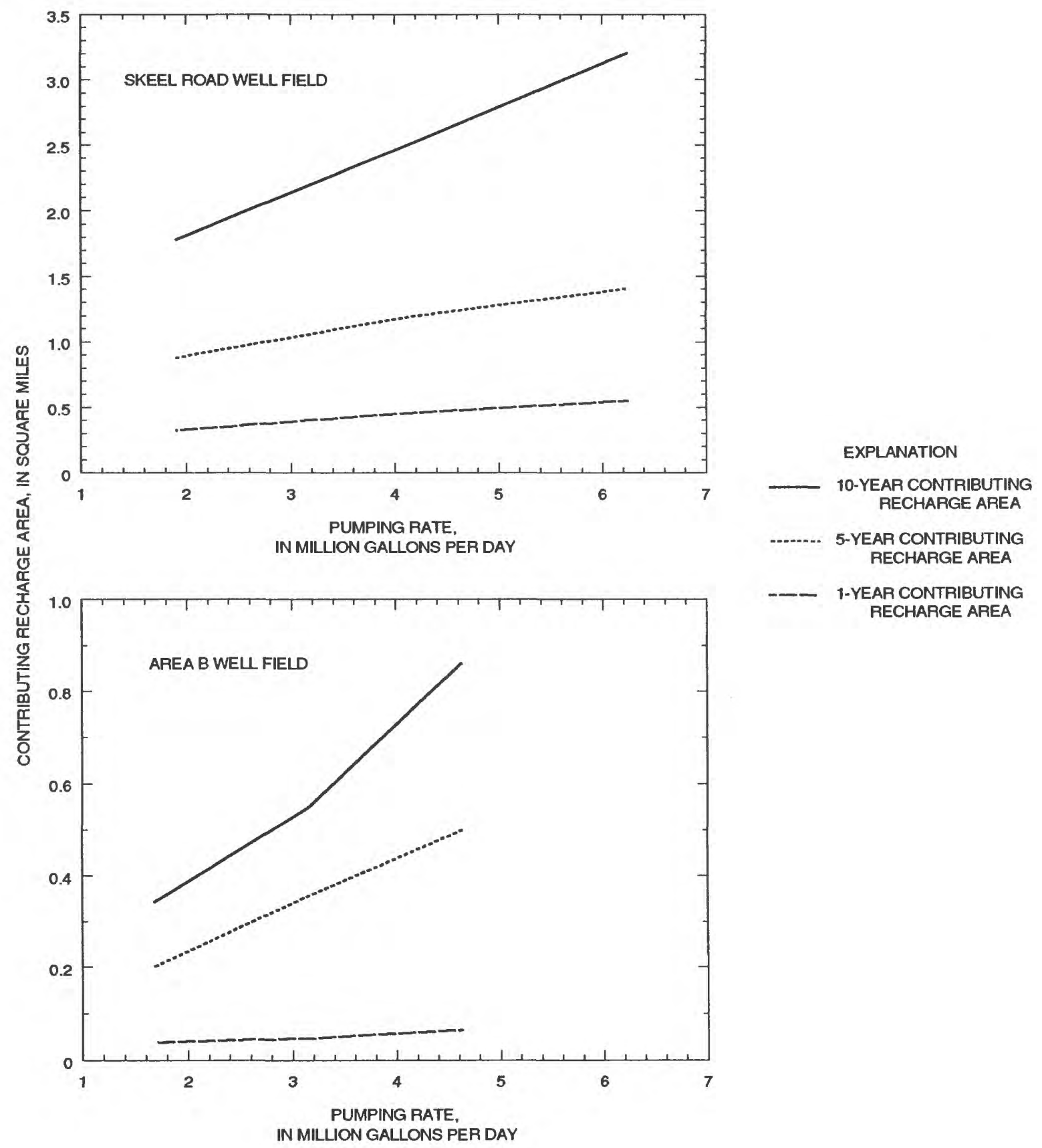

Figure 15. Change in contributing recharge areas in relation to pumping rates at Skeel Road and Area B Well Fields, Wright-Patterson Air Force Base, Ohio (Pumping rates range from normal pumping (OctoberDecember 1987 averages) to maximum capacity pumping for each well field). 
River Valley. The CRA's for Area B include the Huffman Dam area and, under maximum pumping conditions, part of the East Well Field (which is not pumping in these simulations). The CRA's for Area B also become larger, with increased pumping, to the south along the tributary valley to the Mad River valley.

CRA's for the East Well Field, under normal (1.1 Mgal/d), intermediate (3.7 Mgal/d), and maximum (6.2 Mgal/d) pumping conditions (table 1) are shown in figures 16 through 18 . In these simulations, Skeel Road Well Field is pumping at normal rates, and Area B Well Field is not pumping. The circular CRA's Irend south and east at normal pumping rates (fig. 16); at intermediate and maximum pumping rates, the CRA's shift to the north and northeast (figs. 17 and 18). These simulations show that ground-water flow in Mad River Valley and in the tributary valley to the southeast of Areas A and $\mathrm{C}$ are the main areas contributing recharge to the wells in the East Well Field. Under normal, and to a lesser extent, intermediate pumping conditions, some ground water flows to Hebble Creek, which is not in a concrete channel near the East Well Field and to an unnamed tributary near the East Well Field; this ground water is not captured by the wells.

Under intermediate and maximum pumping, a few cells in the simulated upper model layer go dry. In the actual hydrologic system, pumping at high rates in the vicinity of the East Well Field have, in fact, caused the upper several feet of the aquifer to be dewatered. In 1993, pumping at Huffman Dam and to the west of the East Well Field is suspected to have caused two small lakes to the west of the East Well Field to almost go dry; water levels in wells adjacent to the lakes were 10 to $15 \mathrm{ft}$ below 1987 levels. The East Well Field is near the edge of the buried-valley aquifer, and the valley-train deposits are considerably thinner to the west of the well field. Near the East Well Field and along a northeast-southwest trend, few nodes contribute recharge to the wells (figs. 17 and 18). When the cells go dry in the model, particles of water in the cells to the southwest of the well field have to travel around the dry cells to reach the discharge points at the wells; the resulting traveltimes exceed ten years, and the positions of the particles are not part of the CRA's. The traveltimes and particle paths in the area immediately to the southwest of the well field are therefore unreliable because of the dry cells.

\section{Uncertainty Analyses}

Areas contributing recharge to pumped wells can vary in response to a number of factors. The variation of these areas (hence, the uncertainty in the accuracy of these areas) for Skeel Road and Area B Well Fields, based upon changes in hydraulic parameters of the aquifer, is given in this section.

The effect of pumping at one well field on the CRA of the other well field was determined. For this analysis, pumping rates were held constant at the Area B Well Field while pumping at Skeel Road Well Field was cycled through normal, intermediate, and maximum rates. Rates at Skeel Road Well Field were then held constant as pumping at Area B Well Field was cycled through various pumping rates. Pumping at Skeel Road Well Field does not affect the size or shape of the CRA's of Area B Well Field; likewise, pumping at Area B Well Field does not affect the size or shape of the CRA's of Skeel Road Well Field.

The input parameters to the model and the particle-tracking program were systematically changed to examine the effects of uncertainties in hydrogeologic parameters on the areal extent of the CRA's. These input parameters included hydraulic conductivity or transmissivity, effective porosity, areal recharge, and riverbed conductance. Examination of the sensitivity analyses of the model by Dumouchelle and others (1993) and initial CRA analyses indicated that flows in the buried-valley aquifer and flows from the upland bedrock were most likely to affect the CRA's of Skeel Road Well Field (figs. 7 through 9). Similar analyses of the Area B Well Field indicated that rates of infiltration from the Mad River, flows from Hills 1 and 2, and ground-water flow under Huffman Dam would most likely affect the CRA's of Area B Well Field (figs. 7 through 9).

Changes in hydraulic conductivity and transmissivities $\left(K_{1 h}, T_{2}, T_{3}\right)$ of the glacial-drift aquifer significantly affect the size and shape of the 1- and 5-year CRA's for the Skeel Road Well Field. The relations between the CRA's and horizontal hydraulic conductivities of the buried-valley aquifer and in the upland bedrock are shown in figure 19. Porosity variations in the buried-valley aquifer also have a great effect on the CRA's; increases in porosity decrease the CRA's (fig. 20). Changes in horizontal hydraulic conductivity and porosity in the upland bedrock have no effect on the CRA's of Skeel Road Well Field (see also figs. 19 and 20). 


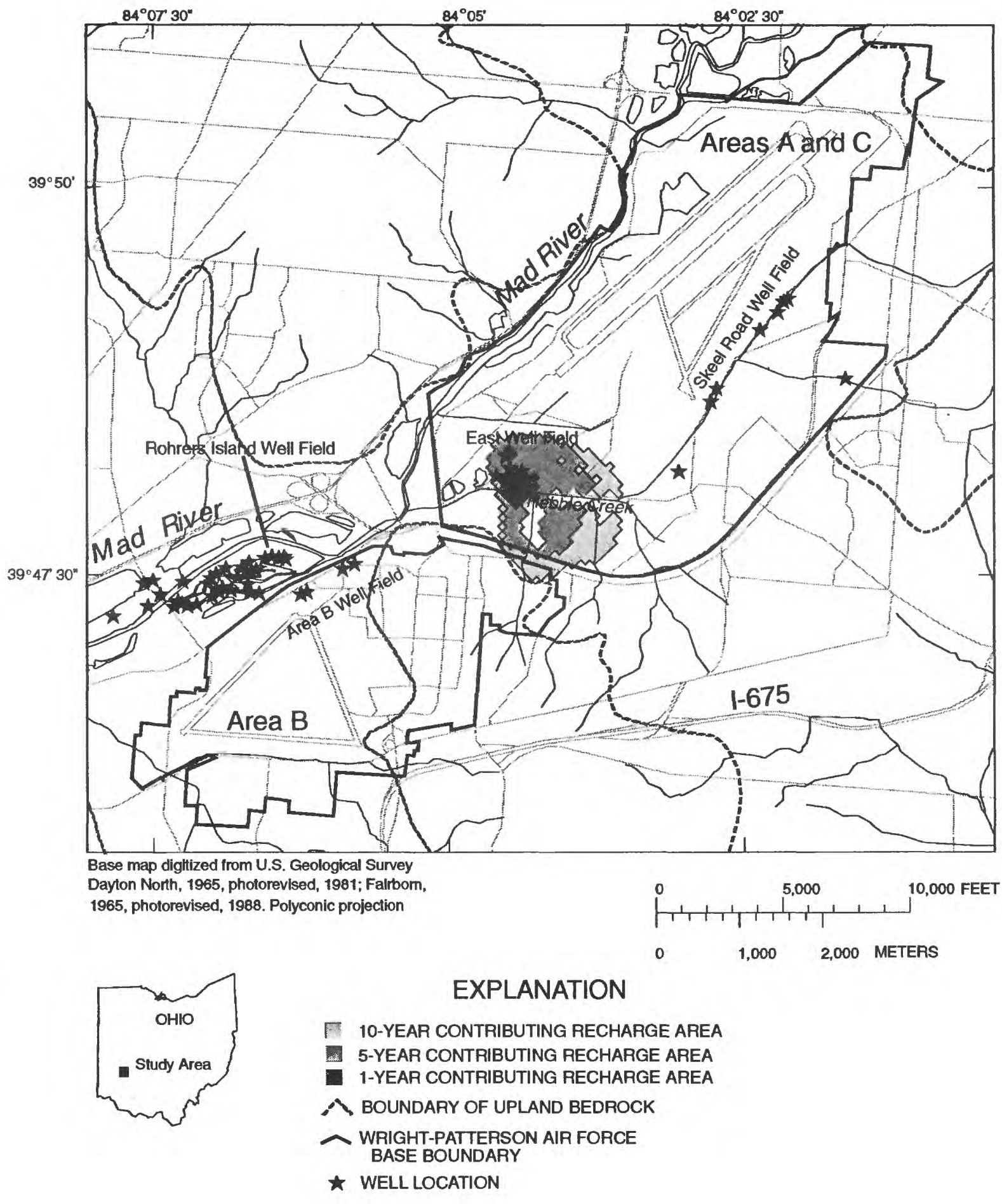

Figure 16. Contributing recharge areas to the East Well Field under October-December 1987 pumping conditions (1.1 million gallons per day). 


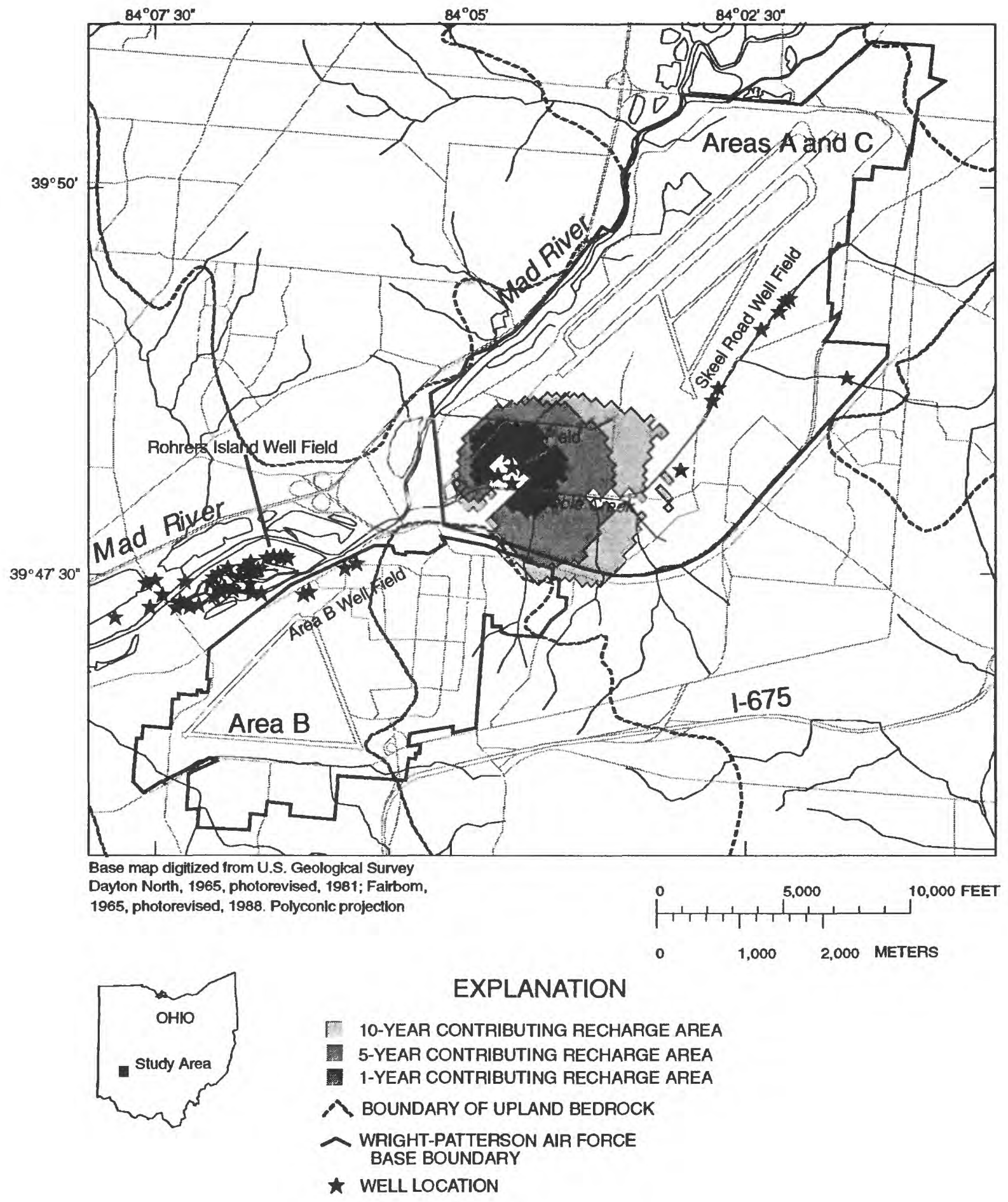

Figure 17. Contributing recharge areas to the East Well Field under intermediate pumping conditions (3.7 million gallons per day). 


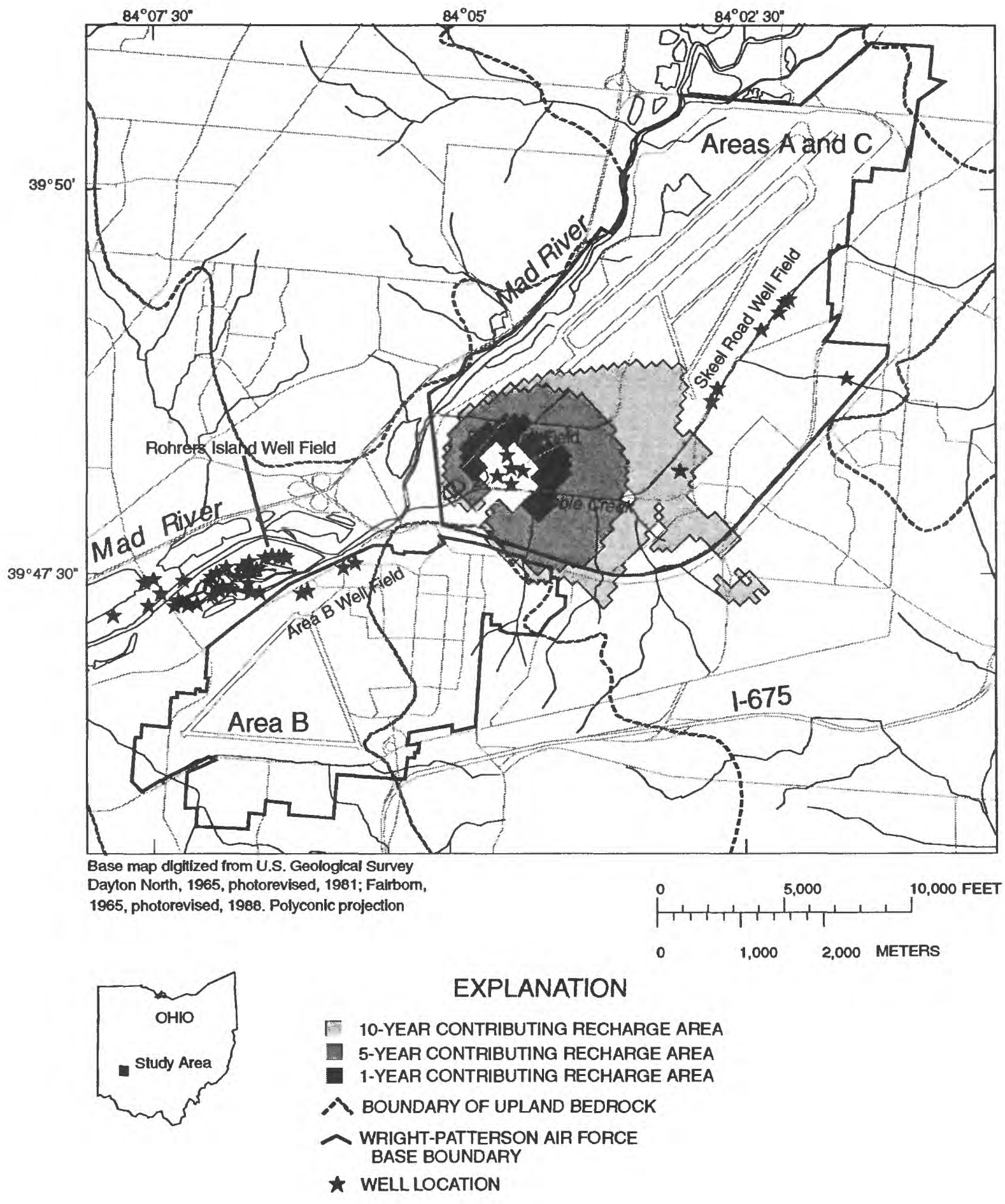

Figure 18. Contributing recharge areas to the East Well Field under maximum capacity pumping conditions (6.2 million gallons per day). 


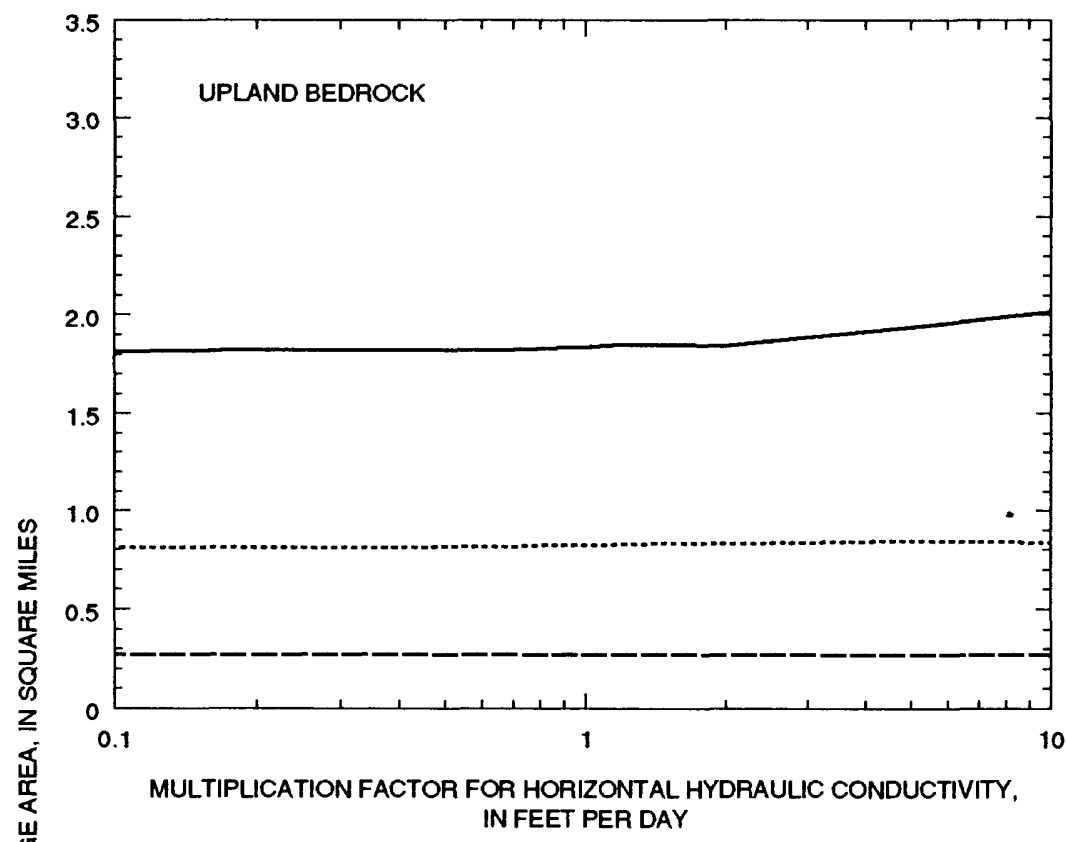

EXPLANATION

10-YEAR CONTRIBUTING RECHARGE AREA

5-YEAR CONTRIBUTING RECHARGE AREA

1-YEAR CONTRIBUTING RECHARGE AREA

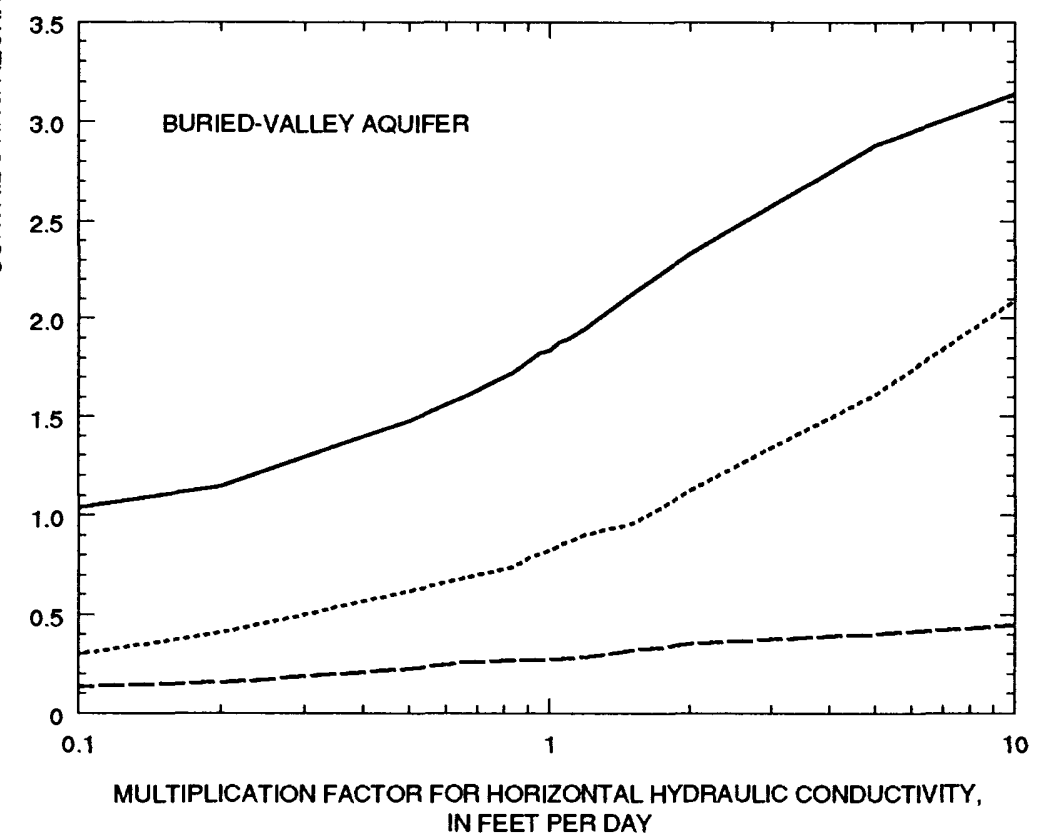

Figure 19. Variations of the contributing recharge areas of Skeel Road Well Field, Wright-Patterson Air Force Base, Ohio, in relation to changes in horizontal hydraulic conductivity of the upland bedrock and buried-valley aquifer under normal pumping conditions. 


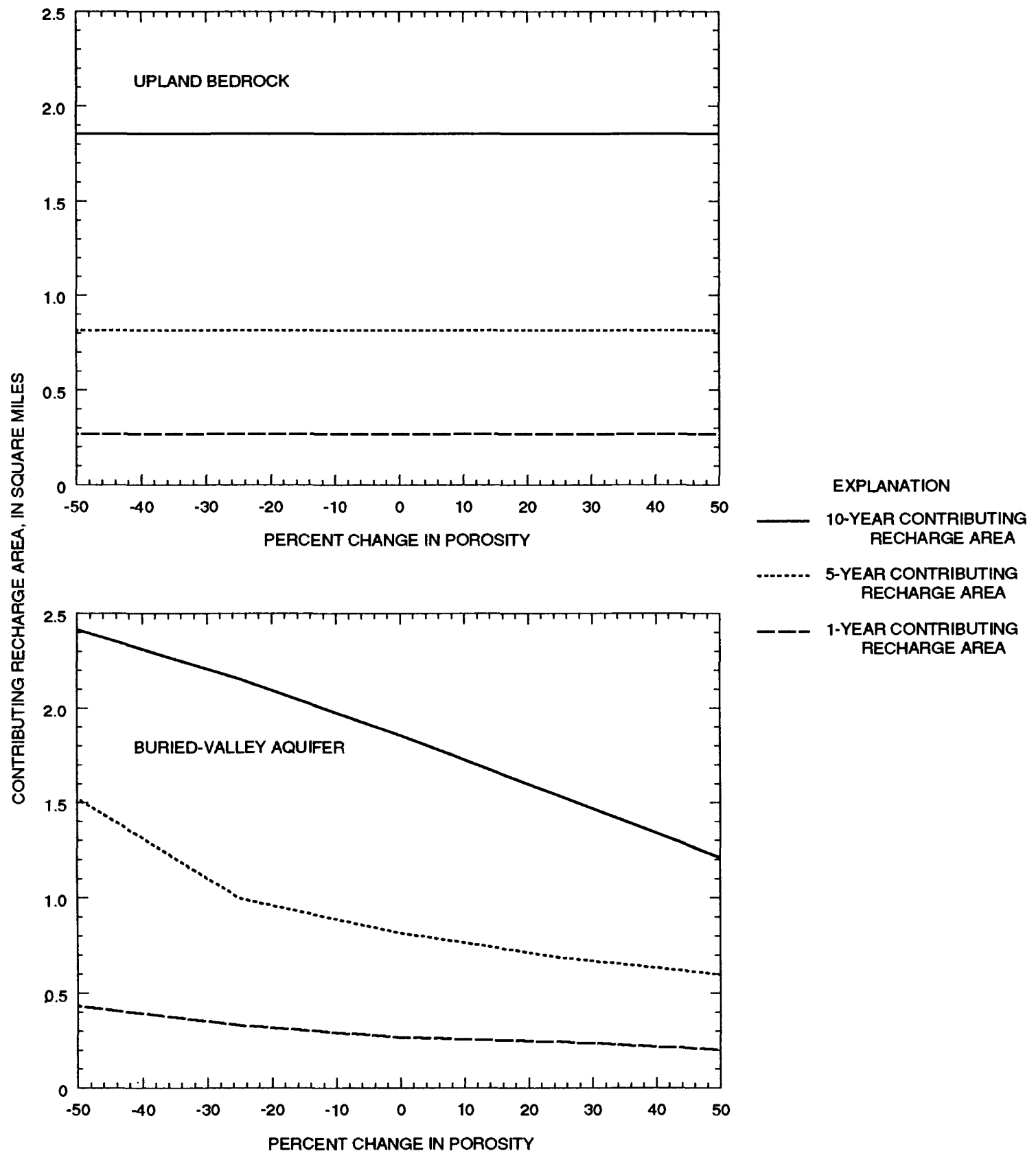

Figure 20. Variations of the contributing recharge areas of Skeel Road Well Field, Wright-Patterson Air Force Base, Ohio, in relation to changes of porosity of the upland bedrock and buried-valley aquifer under normal pumping conditions. 
The Area B wells are completed in the valleytrain deposits near the Mad River and near upland bedrock. To examine the effects on the size of the CRA's on flow from the upland bedrock and flow under Huffman Dam, horizontal hydraulic conductivities and porosities for the upper model layer $\left(\mathrm{K}_{1 \mathrm{~h}}\right)$ were varied, under normal pumping. Changes in $\mathrm{K}_{1 \mathrm{~h}}$ have little affect on the size of the 1- or 5-year CRA's, except at much higher horizontal hydraulic conductivities (fig. 21). As shown in figure 22, porosity changes in the buried-valley aquifer and upland bedrock also have little affect on the size of the CRA's. Horizontal hydraulic conductivity and porosity variations in the bedrock have a slight effect on the size of the CRA's because of the proximity of upland bedrock to the wells. Riverbed hydraulic conductance $\left(K_{\text {riv }}\right)$ was also varied to examine the effect on the CRA's of Area B Well Field because of the proximity of the Mad River and the probable effect of induced infiltration, as shown on figures 12 through 14. However, the results of these variations, shown in figure 23 , indicate that variations in $\mathrm{K}_{\text {riv }}$ do not affect the size of the CRA's. As the CRA's expand, more water from the Mad River is available to the wells. Hydrologic boundaries near the Area B Well Field - upland bedrock, the well field at Rohrer's Island, and the Mad River - cause the CRA's to expand up the Mad River Valley. This result is expected, because simulated flows from Mad River South (fig. 7) and flow through Huffman Dam (fig. 9) also are not sensitive to changes in $\mathrm{K}_{\mathrm{riv}}$. Pumping variations at Rohrer's Island were not examined in these analyses because the well field has maintained constant pumping rates over many years.

\section{Limitations of Tracking Procedure}

As stated previously in this report, the model on which the CRA's are based has limitations that may affect the CRA's. The particle-tracking code also has limitations, which are outlined here. Mercer and Faust (1986) summarize the limitations and sources of error in modeling, and Pollock (1989) discusses the limitations of the particle tracking procedure at length. The most significant limiting factor in particle tracking, and therefore in the contributing recharge analyses presented herein, is the numerical model on which the analyses are based. The numerical model from which the heads and flows are generated and used in particle tracking is a numerical representation of the natural flow system. Numerical approximations, convergence tolerances, and scale limitations can all affect how well the model mimics the actual flow system. Grid structure, boundary definitions, and calibration data also can affect the accuracy of the model and therefore the particle tracking and delineation of a CRA. Errors from numerical approximations are assumed to be minimized by trial-and-error adjustment during calibration, but a discussion of the scale limitations is required here. The model developed previously was designed to investigate regional ground-water flow and more local flow, such as flow to smaller streams, may not be well represented by the model. However, the analyses presented in this report indicate that local flow, at the scale of CRA's, is well represented (for example, fig. 11). A complete discussion of the limitations of the model is given in Dumouchelle and others (1993).

The particle-tracking scheme used by MODPATH is valid only for computing and interpolating advective velocities from intercell flows such as those output by MODFLOW. Accordingly, the CRA's are based on advective particle movement and traveltimes - no diffusion or dispersion is incorporated into the movement of particles that make up the CRA's.

The analyses presented herein are based on a model of steady-state conditions-changes in pumping or other stresses in the system over time may affect the particle pathlines and traveltimes incorporated into the CRA's. Since construction of the model, several factors have altered the ground-water-flow system. The most significant factor is the addition of pumped wells to the area. Wells currently (1994) producing approximately $3 \mathrm{Mgal} / \mathrm{d}$ have been placed on the downstream side of Huffman Dam, and a well (extraction well) producing approximately $0.9 \mathrm{Mgal} / \mathrm{d}$ has been placed about 1 mi northeast of Huffman Dam (fig. 24). The effect of these pumping centers on the size of the Skeel Road and Area B Well Fields was examined by use of a predictive simulation (fig. 24).

Current (1994) pumping at the Huffman Dam wells and the extraction well do not appreciably affect the size or the shape of either the CRA's of the Area B or Skeel Road Well Fields under normal pumping conditions. Results of the particle-tracking analyses indicate that additional wells will alter the ground-waterflow system in the vicinity of Huffman Dam and will affect the CRA's for the East Well Field. The CRA's for Area B, under intermediate and maximum pumping (fig. 14 and 15, respectively) would not extend into Areas A and C. Further expansion of the CRA's to the south of the Area B wells is likely under these 


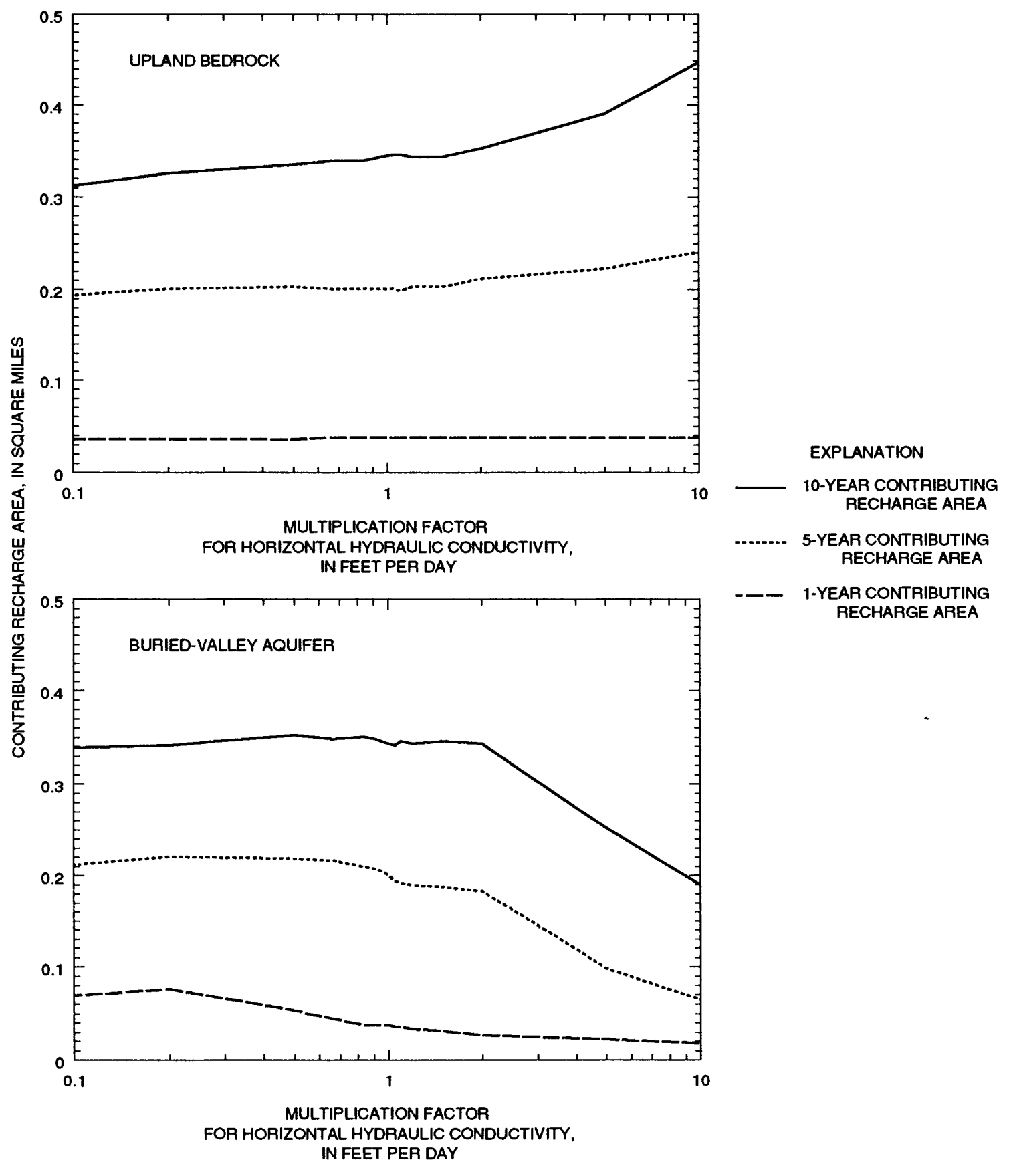

Figure 21. Variations of the contributing recharge areas of Area B Well Field, Wright-Patterson Air Force Base, Ohio, in relation to changes of horizontal hydraulic conductivity of the upland bedrock and buriedvalley aquifer under normal pumping conditions. 


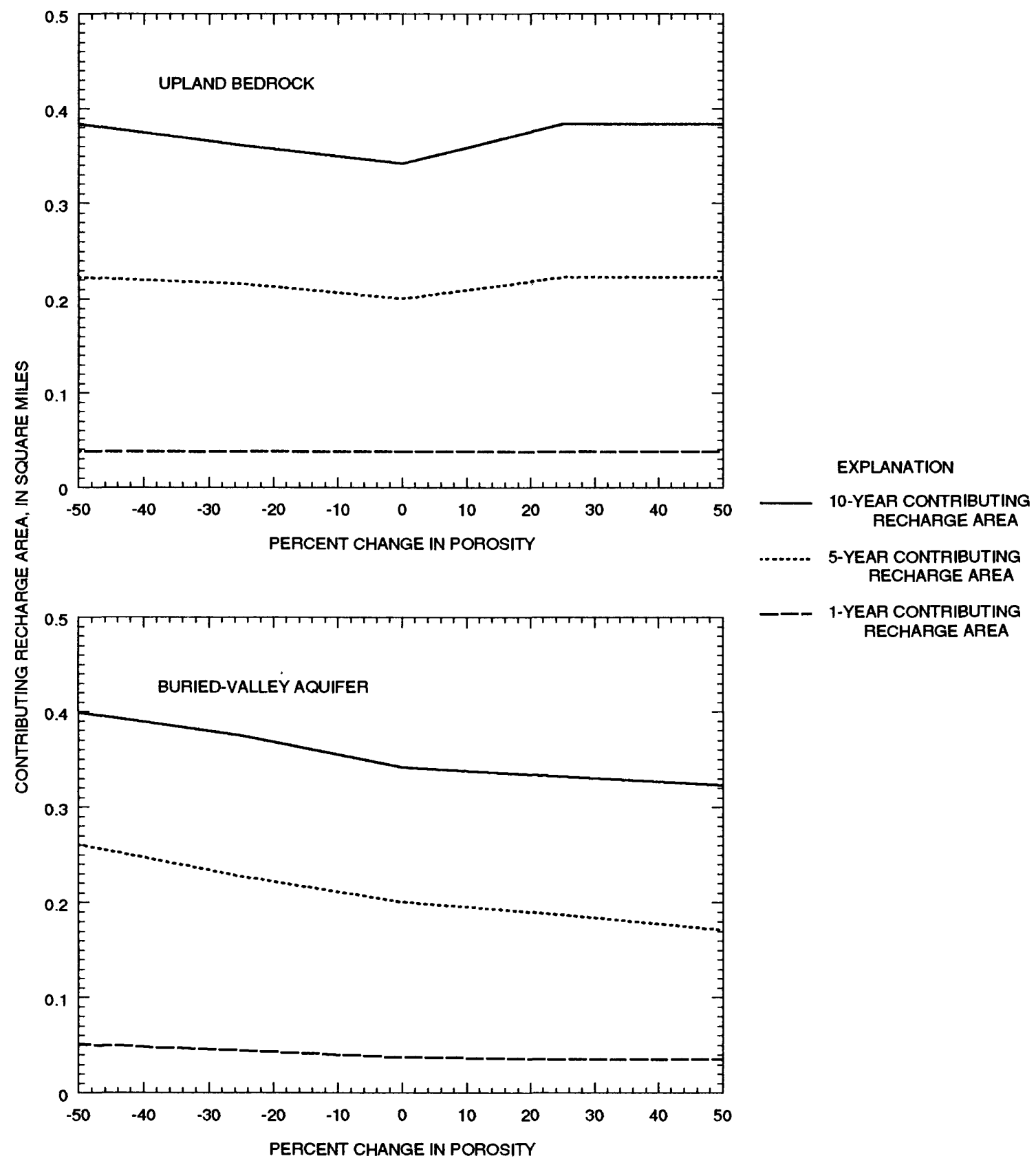

Figure 22. Variations of the contributing recharge areas of Area B Well Field, Wright-Patterson Air Force Base, Ohio, in relation to changes of porosity of the upland bedrock and buried-valley aquifer under normal pumping conditions. 


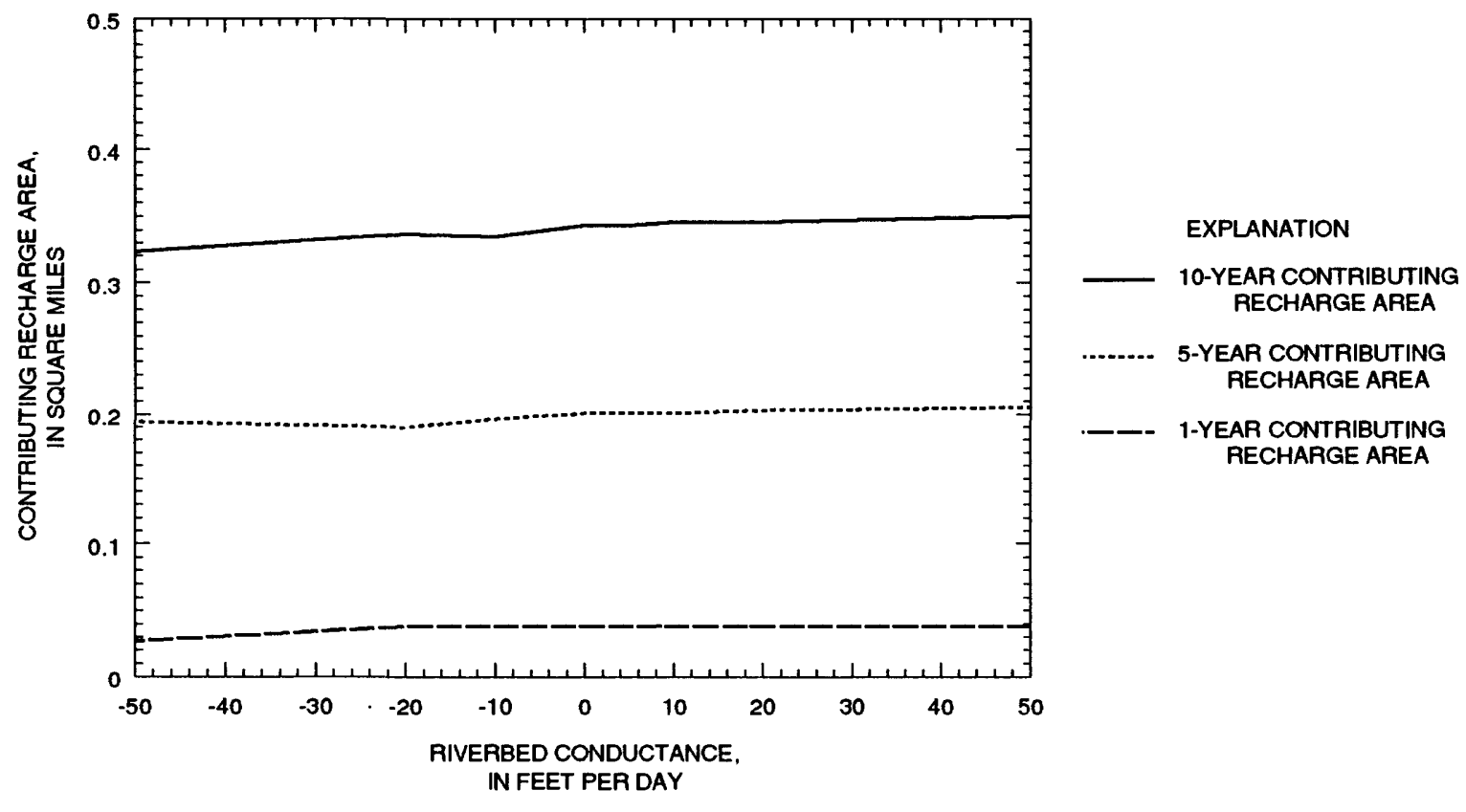

Figure 23. Variations of the contributing recharge areas of Area B Well Field, Wright-Patterson Air Force Base, Ohio, in relation to changes of riverbed conductance under normal pumping conditions.

conditions. The CRA's for the East Well Field would shift more to the south and probably would extend further to the northeast and southeast, owing to the additional stress to the northwest. The decreased water levels in the area of Huffman Dam from the additional pumping would possibly decrease the total yield expected from the East Well Field.

\section{SUMMARY AND CONCLUSIONS}

The contributing recharge areas (CRA's) of the Skeel Road, East, and Area B Well Fields on WrightPatterson Air Force Base were delineated by use of a particle-tracking code that uses hydraulic head and flow data generated by a previously developed numerical ground-water-flow model. Hypothetical particles of water are simulated in the flow field and tracked, in relation to time, to discharge locations. The particles of water that were initially on the water table (recharge) and discharged to a water-supply well in one of the well fields on the Base are considered to be in the CRA for that well field. A geographic information system was used to help delineate 1-, 5-, and 10-year CRA's for each of the well fields on the Base.

Three possible pumping scenarios at the three well fields were examined; increased pumping at each of the well fields resulted in the largest CRA's, with a nearly linear relation between pumping rate and area. The input parameters to the model and the particletracking program were systematically changed to examine the effects of uncertainties in hydrogeologic parameters, such as hydraulic conductivity and recharge, on the areal extent of the CRA's for the Skeel Road and Area B Well Fields. This type of analysis was not completed for East Well Field because it has not been used since 1987 , owing to water-quality concerns.

Results from the simulation and subsequent particle tracking analyses indicate that the CRA's of the Skeel Road Well Field are generally oval and extend northward up the Mad River Valley. With 


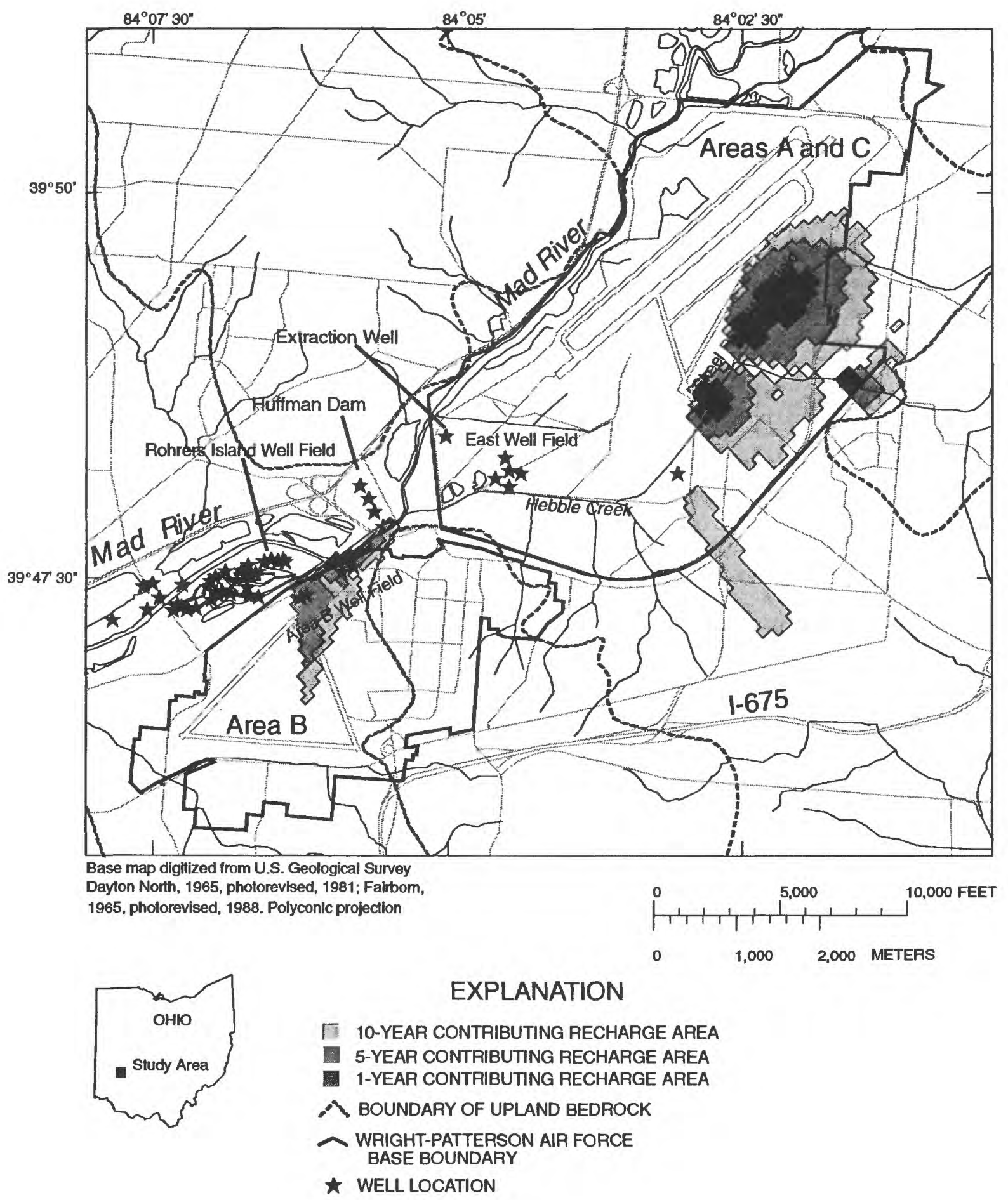

Figure 24. Contributing recharge areas to the Skeel Road and Area B Well Fields under current (1994) pumping conditions, including pumping of wells at Huffman Dam. 
increased pumping, the CRA's extend northward toward the Mad River. The sizes of the 1-, 5-, and 10-year CRA's of the Skeel Road Well Field, under maximum pumping conditions, are approximately $0.5,1.5$, and $3.2 \mathrm{mi}^{2}$, respectively. Uncertainties in the values of horizontal hydraulic conductivity and porosity of the valley-train deposits have the largest effect on the size of the CRA's. No effect is seen on the size or shape of the CRA's of Skeel Road when horizontal hydraulic conductivity of the upland bedrock and riverbed conductance are varied.

The CRA's of the Area B Well Field extend north, up the Mad River Valley and south, up a tributary buried valley of the Mad River Valley. As pumping increases, the CRA's extend further up the Mad River Valley, into Areas A and C. The sizes of the 1-, 5-, and 10-year CRA's of Area B Well Field, under maximum pumping conditions, are approximately 0.1 , 0.5 , and $0.9 \mathrm{mi}^{2}$, respectively. The CRA's are smaller than the CRA's of Skeel Road Well Field because of lower pumping rates and more induced infiltration from surface-water sources. The CRA's of Area B Well Field are not significantly affected by any of the hydrogeologic parameters tested, although the sensitivity analyses of the model indicate that the upland bedrock should affect the CRA's. Variation in riverbed conductance does not affect the size of the CRA's of the Area B Well Field, although the wells are in close proximity to the Mad River, and induced infiltration controls the size of the CRA's. Pumping at the nearby
Rohrer's Island Well Field, flow from the nearby upland area, and the close proximity of the Mad River to the pumping center controls the shape and size of the CRA's of Area B Well Field.

At normal pumping rates, the CRA's of the East Well Field are generally circular but are affected by ground-water discharge to nearby streams. The 1-, 5-, and 10-year CRA's of the East Well Field, under maximum pumping conditions are approximately $0.2,1.2$, and $2.4 \mathrm{mi}^{2}$, respectively; at greater than normal pumping rates, however, limitations in the model decrease the usefulness of the CRA analysis for this well field.

The ground-water-flow system of the Base has undergone significant changes since the completion of the ground-water-flow model. Increased withdrawals of ground water in the vicinity of Huffman Dam were input to the model to simulate current (1994) pumping conditions. The additional pumping does not seem to affect the CRA's for Area B and Skeel Road Well Fields under normal pumping conditions. Under maximum pumping conditions at the Area $\mathrm{B}$ Well Field, its CRA's would likely propagate further southward, instead of extending into Areas A and C. The CRA's of the Skeel Road Well Field would not be appreciably affected by the pumping at Huffman Dam. The CRA's of the East Well Field would probably shift more to the northeast and southeast, owing to the additional pumping stress imposed on the ground-water-flow system. 


\section{REFERENCES CITED}

Casey, G.D., 1992, Hydrogeology of the basal confining unit of the carbonate aquifer system in the Midwestern Basins and Arches Region of Indiana, Ohio, Michigan, and Illinois: U.S. Geological Survey Open-File Report 92-489, 2 sheets, scale 1:1,000,000.

Cross, W.P., and Feulner, A.J., 1964, Anomalous streamflow-ground-water regimen in the Mad River basin, near Springfield, Ohio: U.S. Geological Survey Professional Paper 475-D, p. D198-D201.

Dames \& Moore, Incorporated, 1986a, Installation Restoration Program report, site investigation report-landfills 8 and 10: Prepared for Wright-Patterson Air Force Base [variously paginated]. 1986b, Installation Restoration Program report, site investigation report-landfill 12: Prepared for Wright-Patterson Air Force Base [variously paginated].

Dumouchelle, D.H., Schalk, C.W., Rowe, G.L., de Roche, J.T., 1993, Hydrogeology, simulated ground-water flow, and ground-water quality, Wright-Patterson Air Force Base, Ohio: U.S. Geological Survey WaterResources Investigations Report 93-4047, 152 p.

IT Corporation, 1990, Installation Restoration Program report, environmental investigation of ground-water contamination at Wright-Patterson Air Force Base, Ohio: Dayton, Ohio, Battelle Environmental Management Operations, prepared for Wright-Patterson Air Force Base [variously paginated].

Johnson, A.I., 1967, Specific yield-compilation of specific yields for various materials: U.S. Geological Survey Water-Supply Paper 1662-D, 74 p.

McDonald, M.G., and Harbaugh, A.W., 1988, A modular three-dimensional finite-difference ground-water flow model: U.S. Geological Survey Techniques of WaterResources Investigations, book 6, chap. A1, $586 \mathrm{p}$.

Mercer J.W., and Faust, C.R., 1986, Ground-water modeling; Columbus, Ohio, National Water Well Association, $60 \mathrm{p}$.

Morrissey, D.J., 1989, Estimation of the recharge area contributing water to a pumped well in a glacial-drift, river-valley aquifer: U.S. Geological Survey WaterSupply Paper 2338, 41 p.
Norris, S.E., and Spieker, A.M., 1966, Ground-water resources of the Dayton area, Ohio: U.S. Geological Survey Water-Supply Paper 1808, $167 \mathrm{p}$.

Ohio Environmental Protection Agency, 1992, Ohio Wellhead Protection Program: Columbus, Ohio, Ohio Environmental Protection Agency, Division of Drinking and Ground Waters, May 1992, 96 p.

Pollock, D.W., 1989, Documentation of computer programs to compute and display pathlines using results from the U.S. Geological Survey modular three-dimensional finite-difference ground-water flow model: U.S. Geological Survey Open-File Report 89-381, 188 p.

Reilly, T.E., and Pollock, D.W., 1993, Factors affecting areas contributing recharge to wells in shallow aquifers, U.S. Geological Survey Water-Supply Paper 2412, $21 \mathrm{p}$.

Schalk, C.W.. 1992, Ground-water levels and flow in the vicinity of Wright-Patterson Air Force Base, Ohio, October-December, 1987: U.S. Geological Survey Water-Resources Investigations Report 92-4022, 1 sheet, scale $1: 46,980$.

Shindel, H.L, Klingler, J.H., Mangus, J.P., and Trimble, L.E., 1991, Water resources data, Ohio, water year 1991: U.S. Geological Survey Water-Data Report OH-91-2, 430 p.

U.S. Environmental Protection Agency, 1993, Designated Sole Source Aquifers nationally-fact sheet with designated aquifers and pending petitions listed: Washington D.C., Environmental Protection Agency, Office of Water, Ground-Water Protection Division, 12 p.

Walton, W.C., and Scudder, G.D., 1960, Ground-water resources of the valley-train deposits in the Fairborn area, Ohio: Ohio Department of Natural Resources, Division of Water Technical Report 3, 57 p.

Weston, Roy F., Incorporated, 1983, Installation Restoration Program report, Phase II-problem confirmation and quantification study: Prepared for Wright-Patterson Air Force Base [variously paginated]. 1989, Installation Restoration Program report, stage 2 report: Prepared for Wright-Patterson Air Force Base, 3 v. [variously paginated]. 